\title{
FRAMING FEMINIZATION OF AGRICULTURE: FROM GENDER- ENVIRONMENTAL THEORIES TO INTERNATIONAL ENVIRONMENTAL LAW
}

\author{
SABRINA BRIZIOLI \\ Phd-Research Fellow \\ University of Perugia - School of Law \\ sabrina.brizioli@unipg.it
}

Fecha de recepción: 29 de octubre de 2020 / Fecha de aceptación: 3 de febrero de 2021

\begin{abstract}
Since 70s the debate about women and environment has registered a considerable change in the perception of the role played by women and different conceptual and methodological approaches developed to deal with the women - gender - environment interrelationship and to compare the feminist standpoint with the androcentric culture that makes male (andros) at the center of the economic, socio-cultural and political life.

This paper, which focuses on the feminization of agriculture phenomenon, i.e. women's increasing work and responsibilities in agriculture, explores its meaning in terms of women's empowerment and examines the contribution of feminist strands of thought (such as ecofeminism - women and environment gender, environment and sustainable development) in fostering the gender paradigm in environmental concerns, plans for agricultural and rural development.
\end{abstract}

The author aims at verifying whether gender theories have influenced international environmental law to introduce feminist perspectives, women's rights and experiences at the core of environmental issues and (en)-gendered some changes in agriculture, mainly those aspects that have consistently been associated with masculinity. 
RESUM: Des dels anys 70, el debat sobre les dones i el medi ambient ha registrat un canvi considerable en la percepció del paper que exerceixen les dones i s'han desenvolupat diferents enfocaments conceptuals i metodològics per tractar la interrelació dona - gènere - medi ambient, així com per comparar la perspectiva feminista amb la cultura androcèntrica que fa del mascle (andros) el centre de la vida econòmica, sociocultural i política.

Aquest article, que se centra en la feminització del fenomen de l'agricultura, és a saber, el creixent treball i responsabilitats de les dones en l'agricultura, explora el seu significat en termes d'empoderament de les dones i examina la contribució de les tendències de pensament feministes (com ara l'ecofeminisme - dones i medi ambient - gènere, medi ambient i desenvolupament sostenible) en el foment del paradigma de gènere en les preocupacions mediambientals $i$ en els plans per al desenvolupament agrícola i rural.

L'autora té com a objectiu verificar si les teories de gènere han influït en el dret internacional del medi ambient per introduir perspectives feministes $i$ drets $i$ experiències de les dones en el nucli de les qüestions ambientals, així com si han gener(itz)at alguns canvis en l'agricultura, principalment en aquells aspectes que sempre han estat associats amb la masculinitat.

RESUMEN: Desde los años 70, el debate sobre la mujer y el medio ambiente ha registrado un cambio considerable en la percepción del papel que desempeñan las mujeres $y$ se han desarrollado diferentes enfoques conceptuales y metodológicos para tratar la interrelación mujer - género medio ambiente y para comparar el punto de vista feminista con la cultura androcéntrica que hace del hombre (andros) el centro de la vida económica, sociocultural y política.

Este trabajo, que se centra en el fenómeno de la feminización de la agricultura, es decir, el aumento del trabajo y las responsabilidades de las mujeres en la agricultura, explora su significado en términos de empoderamiento de las mujeres y examina la contribución de las corrientes de pensamiento feminista (como el ecofeminismo - mujeres y medio ambiente - género, medio ambiente y desarrollo sostenible) en el fomento del paradigma de género en las preocupaciones ambientales, los planes de desarrollo agrícola y rural. 
La autora pretende comprobar si las teorías de género han influido en el derecho internacional del medio ambiente para introducir las perspectivas feministas, los derechos y las experiencias de las mujeres en el centro de las cuestiones medioambientales y gener(iz)ar algunos cambios en la agricultura, principalmente en aquellos aspectos que se han asociado sistemáticamente a la masculinidad.

KEYWORDS: Feminization of Agriculture - Women Empowerment Ecofeminism - Sustainable Development - Gender

PARAULES CLAU: Feminització de l'Agricultura - Empoderament de les Dones - Ecofeminisme - Desenvolupament Sostenible - Gènere

PALABRAS CLAVE: Feminización de la Agricultura - Empoderamiento de las Mujeres - Ecofeminismo - Desarrollo Sostenible - Género

\section{LIST OF CONTENTS:}

Introduction. 1. "Men Work and Women Plough": Zooming Feminization of Agriculture and Women's Empowerment. 2. Gender Theories on the Move. 2.2 Ecofeminism. 2.3 Women and the Environment. 2.4 Gender, Environment and Sustainable Development. 3. From Theories to Practice: Greening Women in International Law. 4. Mapping the Rumors of Feminization of Agriculture in International Environmental Law. Conclusion. References.

Feminist methods emphasize conversations and dialogue rather than the production of a single, triumphant truth*

\section{INTRODUCTION ${ }^{\star *}$}

What does the feminization of agriculture phenomenon, i.e. women's increasing work and their responsibilities in agriculture, mean in terms of women's empowerment? Do women play the role of independent farmworkers or food producers? Has agriculture adopted feminine features because of the increasing engagement of women through time? Did international environmental law record such a trend? 
To answer these questions it is necessary to firstly consider the economic forces and socio-cultural relationships that have contributed to shape the feminization phenomenon, especially in agriculture, to then outline whether this trend and its consequences were detected by feminist and gender approaches and brought to the attention of the international law ${ }^{1}$. In fact, changes in the farming systems have been strongly influenced by gender relations that determine what is considered productive or reproductive labour ${ }^{2}$, the distribution of resources and the allocation of inputs ${ }^{3}$.

Women have always performed traditional and sustainable practices, taking charge of lands and habitats because of their natural closeness to biological cycles, but such an involvement grew markedly as men either migrated or engaged in off-farm employment ${ }^{4}$. Despite this, an official recognition of women's role is rarely present at national and local level or within indigenous customary law ${ }^{5}$ and they have resulted to be more visible as a homogeneous workforce than considered to be as independent producers.

Moreover, there is little evidence that the growing women's workload and farmwork have re-addressed the way decisions are taken in household or

\footnotetext{
- Hilary Charlesworth, "Feminist Methods in International Law", in The American Journal of International Law, p. 379-394, at p. 379.

** This study was presented at the V Tarragona International Environmental Law Colloquium (TIEC) 25-26 June 2020 - Universitat Rovira i Virgili (Tarragona). The analysis especially concerns the topic "New and Critical Developments of Ecofeminism, Intersectionality and Multiple Discriminations, Environmental and Gender-critical Theories: Exploring New Masculinities and Environmental Law under Gender Perspectives".

1 Hilary Charlesworth, "Women as Sherpas: Are Global Summits Useful for Women?", in Feminist Studies, vol. 22, issue 3, 1996, p. 537-547.

2 The concepts "productive" and "reproductive" work are used in this study to underline the distinction of women's labour in the productive and reproductive spheres. The former refers to remunerated work in the market or agricultural production, the latter deals with "domestic" tasks carried out by women such as housework and childcare. In this sense see Tattwamasi Paltasingh, Lakshmi Lingam, "Production and Reproduction in Feminism: Ideas, Perspectives and Concepts", in IIM Kozhikode Society \& Management Review, vol. 3, issue 1, 2014, p. 4553.

${ }^{3}$ Alberto Alesina, Paola Giuliano, Nathan Nunn, "On the Origin of Gender Roles: Women and the Plough", in Quarterly Journal of Economics, vol.128, issue 2, 2013, p. 469-530.

${ }^{4}$ Hom Nath Gartaula, Anke Niehof, Leontine Visser, "Feminisation of Agriculture as an Effect of Male Out-migration: Unexpected Outcomes from Jhapa District, Eastern Nepal", in The International Journal of Interdisciplinary Social Sciences, 2010, vol. 5, p. 565-577; Kaitlyn Spangler, Maria Elisa Christle, "Renegotiating Gender Roles and Cultivation Practices in the Nepali Mid - Hills: Unpacking the Feminization of Agriculure", in Agriculture and Human Values, vol. 37, 2020, p. 415-432.

${ }^{5}$ In this study, the expression "indigenous customary law" means principles, procedures, rules and rights that local communities or indigenous people have used, upheld and passed on for thousand of years.
} 
community since, as suggested by C.S. Dolan and K. Sorby, "gender equality is not simply a matter of equal numbers of men and women in employment but rather the degree to which their work contributes to the women's well-being and empowerment"6.

Various lines of thought tried to restore the gender gap and redress the interconnection between society, gender and environment 7 (namely ecofeminism and other approaches described in this study $)^{8}$ by giving birth to a transnational and international discourse to create spaces for the subaltern voices of women in the environmental law framework. Under a constructionist point of view ${ }^{9}$, these conceptualizations attempted to spread the image of women as a driving force to demand for more inclusion in environmental planning, budgeting and representation ${ }^{10}$ in policy-making processes ${ }^{11}$. A certain kind of awareness of women deepened and broadened engagement in agriculture has been perceived in declarations, plans of action and documents adopted by international conferences in recent years but gender-blindness is still present in agriculture because of a very low level of recognition of women

${ }^{6}$ Cathrine Dolan, Kristina Sorby, "Gender and Employment in High-Value Agriculture Industries", Agriculture and Rural Development Working Paper 7, Washington DC, World Bank. 2003, at p.43.

${ }^{7}$ Val Plumwood, "Nature, Self, and Gender: Feminism, Environmental Philosophy, and the Critique of Rationalism", in Hypatia, vol. 6, issue 1, 1991, p. 3-27.

${ }^{8}$ The study does not use the commonest concepts and conceptual shifts to describe the main trends concerning women and environment. The author attempts to describe the contents of the most relevant approaches and the way women's issues have been conceptualized through time rather than to list them in a theoretical manner. For this, different perspectives and strand of thoughts are named focusing on their relevant aspects not following the conventional and well known categories.

${ }^{9}$ In this study, the feminist perspective and the social constructionism are considered together as critical approaches that endeavor to connect women issues with societal, ideological and institutional contexts. See Janis S. Bohan, "Essentialism, Constructionism, and Feminist Psychology", in Psychology of Women Quarterly, vol. 17, issue 1, 1993, p. 5-21; Marie Withers Osmond, Barrie Thorne, "Feminist Theories. The Social Construction of Gender in Families and Society", in Pauline Boss, William J. Doherty, Ralph La Rossa, Walter R. Schumm, Suzanne K. Steinmetz (eds.), Sourcebook of Family Theories and Methods. A Contextual Approach, Springer Boston, 1993, p. 591-625; Joan L. Biever, Cynthia De Las Fuentes, Lisa Cashion, Cynthia Franklin, "The Social Construction of Gender: A Comparison of Feminist and Postmodern Approaches", in Counselling Psychology Quarterly, vol. 11, issue 2, 1998, p. 163179.

10 This study tackles the "representation issue" having due regard to womens' involvement in various venues and levels of government. Moreover, the analysis examines the way womens' representation has the ability to translate their interests into policy. See Maria C.- EscobarLemmon, Michelle M. Taylor-Robinson (eds.), Representation: The Case of Women, Oxford University Press, New York, 2014.

${ }^{11}$ Elisa Fiaccadori, "The Question of 'Nature': What has Social Constructionism to Offer Feminist Theory?", in Sociology Working Papers, 2006, p. 1-17. 
as independent agents and the sex-determined entitlement of rights to land and resources $^{12}$, particularly deep-rooted in local customs.

The present study seeks to adapt feminist theories to the feminization of agriculture phenomenon in order to figure out women's request for a sociocultural visibility and the critique of non gender-systems to foster a structural transformation of gender assumptions. The article examines the meaning of feminization of agriculture, its features and how it relates to women's empowerment (par.1). This latter concept leads to scrutinize the various feminist frameworks that deal with gender and environmental concerns (par. 2) noting their peculiarities and downsides.

Finally the analysis (par. 3-4) attempts to describe how ecofeminism and gender-environment theories affect international law and the efforts made at the international level to embody the gender perspective.

The author concludes by noting that gender-specific obstacles (such as lack of access to land, equal treatment, suitable working conditions) still remain and female farmers still experience significant disadvantages compared to men. Despite international law declarations and strategy plan asking for equality, the gender bias in agriculture continues and it entails extra efforts for women and their being behind the male counterparts. For this, the analysis seeks to explain the way feminist and gender viewpoints could help to understand the traditional sex-typed division of labour in agriculture ("gender roles") and to mitigate the power asymmetry ("gender inequality") ${ }^{13}$ between the sexes for the control and manage of reproductive economic resources in this sector ${ }^{14}$.

1. "Men Work and Women Plough": Zooming Feminization of Agriculture and Women's Empowerment

\footnotetext{
12 Oliver De Schutter, "The Emerging Human Right to Land", in International Community Law Review, vol. 12, issue 3, 2010, p. 303-334.

${ }^{13}$ Nan Zhu, Lei Chang, "Evolved but Not Fixed: A Life History Account of Gender Roles and Gender Inequality", in Frontiers in Psychology, available at < https://www.ncbi.nlm.nih.gov/pmc/articles/PMC6664064/pdf/fpsyg-10-01709.pdf>. [Retrieved on 27 September, 2020].

${ }^{14}$ Sabin Bieri, "New Ruralities - Old Gender Dynamics? A Reflection on High-value Crop Agriculture in the Light of the Feminizaztion Debates", in Geographica Helvetica, issue 69, 2014, p. 281-290.
} 
The expression "feminization of agriculture" has no clear and agreed explaination. Looking closely at the term "feminization", the Collins Dictionary clarifies that it is the derivative form of the verb "to feminize" meaning "something that involves mainly women or it is thought suitable for or typical of women"15. A different nuance of this term appears in the definition of the Cambridge Dictionary which describes "feminization" as "a process in which more and more women become involved in an activity where there are traditionally more men"16. Both these definitions simply indicate a phenomenon characterised by women's involvement in jobs that consistently concerned men, though this does not necessarily imply changes of masculin schemes in the market or flexibilisation of labour ${ }^{17}$.

In the 70s Esther Boserup foresaw the increasing demand for female labour ${ }^{18}$ in the farming systems in Sud Saharan Africa and South Asia ${ }^{19}$ and the feminist movements, which have occurred afterwards, portrayed feminization of agriculture as the measurable growth of women in the agricultural workforce $e^{20}$ originated by multiple social and economic turning points, such as the agrarian transition, the rise of industrialized means of production and services, urbanization and migratory patterns ${ }^{21}$. Indeed, as said by Oliver De Shutter, "all of these socio-economic events followed gender lines"22.

Thought as a global phenomenon, feminization of agriculture has regional variations and gathers multiple experiences, being more pronounced in rural

\footnotetext{
${ }^{15}$ Collins COBUILD Advanced English Dictionary, v. to feminize, HarperCollins Publishers, at < https://www.collinsdictionary.com/it/dizionario/inglese/feminizes . [Retrieved on 27 September, 2020].

16 Cambridge Dictionary, v. Feminization, Cambridge University Press 2020, at < https://dictionary.cambridge.org/dictionary/english/feminization.>. [Retrieved on 27 September, 2020]

17 Susana Lastarria-Cornhiel, Feminization of Agriculture: Trends and Driving Forces, Background Paper For the World Development Report 2008, Rimisp-Latin American Center for Rural Development - International Development Research Centre, Ottawa, 2006.

${ }^{18}$ Esther Boserup, Woman's Role in Economic Development, Earthscan, London/New York, 1970.

${ }^{19}$ Lourdes Benería, Günseli Berik, Maria S. Floro, Gender, Development, and Globalization. Economics as if all People Mattered, Routledge, New York/London, 2003.

20 Susana Lastarria-Cornhiel, Feminization of Agriculture: Trends and Driving Forces, Background Paper for the World Development Report 2008, p. 1-21, at $<$ https://openknowledge.worldbank.org/handle/10986/9104>. [Retrieved on 28 September, 2020]

${ }^{21}$ Caroline Sweetman (ed.), Women, Land and Agriculture, Oxfam Publishing, Oxford, 1999.

${ }^{22}$ Oliver De Schutter, "The Agrarian Transition and the 'Feminization of Agriculture', in Food and Sovereignty: A Critical Dialogue", in Conference Paper of the International Conference Yale University, September 14-15, 2013, issue 37, p. 1-43.
} 
areas of developing countries, and some scholars have traced its outcomes (even negative consequences) in the agricultural productivity ${ }^{23}$, e.g. lower pay for rural women, decreasing of women's opportunities in education, small-scale female farmers discrimination and adverse impact on food security ${ }^{24}$. It has been said that feminization of agriculture "is a phenomenon easier to describe than it is to explain" 25 and the difficulties of such an explanation lie in the fact that gender relations are complex when linked to changes in agriculture ${ }^{26}$. As a matter of fact, the increasing participation of women in agriculture itself may not be a sign of empowerment, unless farming strategies and policies continue to pursue technical advancement and efficiency targets rather than to tackle and re-address questions of gender inequalities. Moreover, the feminization of agriculture discourse is strongly connected to rural development because rural women are still very dependent on agricultural practices but have benefited little from modern technology in the agri-food system. Indeed, despite women's ability in strengthening the productivity of land and household labour improvement, public-supported programmes generally assist men working on cash crop production and technologies prioritise irrigated land in favorable areas held by male farmers. Rural women, who manage food crop production on strips of land, are often excluded so that they are unable to credit needed to increase their output ${ }^{27}$.

Nevertheless, agriculture can be considered the oldest and widest private sector enterprise initiated by women over 10,000 years ago and women are still today the backbone of a rural workforce which gathers and grows seeds in the backyard of dwellings. Women have always played a central role in horticulture,

\footnotetext{
${ }^{23}$ Alan de Brauw, Jikun Huang, Linxiu Zhang, Scotto Rozelle, The Feminization of Agriculture with Chinese Characteristics, IFPRI Discussion Paper, 2012, p. 1-23, at < http://ebrary.ifpri.org/utils/getfile/collection/p15738coll2/id/126960/filename/127171.pdf.> [Retrieved on 27 September, 2020].

${ }^{24}$ Report Submitted by the Special Rapporteur on the Right to Food, Olivier De Schutter, Women's Rights and the Right to Food, A/ARC/22/50, 24 December 2012, p.14., at https://www.ohchr.org/Documents/HRBodies/HRCouncil/RegularSession/Session22/AHRC2250 English.PDF. [Retrieved on 28 September, 2020].

$\overline{25}$ Janice Jiggins, "The Feminization of Agriculture", in The Brown Journal of World Affairs, vol.5, issue 2,1998, p. 251-262.

${ }^{26}$ Agnes R. Quisumbing, Ruth Meinzen - Dick, Terri L. Raney, André Croppenstedt, Julia A. Behrman, Amber Peterman (eds.), Gender in Agriculture. Closing the Knowledge Gap, FAOSpringer, New York/London, 2014.

${ }^{27}$ Marianna Khachaturyan, Wesley F. Peterson, "Does Gender Really Matter in Agriculture?", in Agricultural Economics, 2018, at <https://agecon.unl.edu/cornhusker-economics/2018/doesgender-matter-agriculture.pdf>. [Retrieved on 27 September, 2020].
} 
dairy, fisheries and other allied sectors being gatherers, homegardeners, plant domesticators, herbalists and seed custodians ${ }^{28}$, but such a mastery in their daily tasks has not led to an equal distribution of resources, uniform access to lands or to credit $^{29}$ yet and means of production have still remained, in many cases, in the hands of men.

Relevant discrepancies denote the quantity and quality of women's work compared to that of men: women comprise $43 \%$ of the workforce, their daily workload is characterized by long hours, mainly $12-14$ hour days, with seasonal variations and they generally earn lower wages than men and are more likely to be paid at piece rate ${ }^{30}$. For women in agriculture time is fragmented and their labour intensive tasks vary according to the specific crop or livestock activities, resources available and equipment used ${ }^{31}$. Women's struggle to obtain lands, means of production and knowledge not only exist between regions and countries, but also within countries and neighbouring communities ${ }^{32}$.

Discrepancies in the type and intensity of women's participation in agriculture are relevant aspects to consider when dealing with feminization of agriculture that has been described as a double-sided phenomenon of labour feminization (i.e. women's increasing workforce in terms of number and time spent in agriculture) and managerial feminization (meaning involvement in decisionmaking processes and representation) $)^{33}$.

Labour feminization in agriculture, as an intensive presence of women in sectors, which are usually prerogative of men, does not necessarily bring right

\footnotetext{
28 Alexsa Guzmán Jiménez, "Conocimientos tradicionales de mujeres mapuches en la agricultura tradicional, territorio Naqche de La Araucanía, Chile", in Cecilia Mayorga Muñoz, Ferdinando Treggiari (eds.) Biodiversidad y conocimientos tradicionales. Perspectivas históricas, socioculturales y jurídicas, Universidad de La Frontera-Università degli Studi di Perugia, Temuco- Perugia, 2018 p. 97-110.

29 Pradeep Joliya, Amita Maurya, Shilpi Sisodia, Virendra Kamalvanshi, Feminization of Agriculture: A Dream Project, in Indian Journal of Economics and Development, 2017 vol. 13, issue 1 , p. 769 ss.

30 See FAO, The Female Face of Farming, <http://www.fao.org/gender/resources/infographics/the-female-face-of-farming/en/.> [Retrieved on 28 September, 2020]

${ }^{31} \mathrm{FAO}$, The Role of Women in Agriculture, Esa Working Paper 11-02, March 2011, < http://www.fao.org/3/am307e/am307e00.pdf.> [Retrieved on 28 September, 2020].

32 Yiching Song, "New" Seed in "Old" China: Impact of the CIMMYT collaborative pragramme on Maize Breeding in South-Western China, Phd Thesis, Wagening Agricultural University, Wageningen, 1998.

${ }^{33}$ Hom Nath Gartaula, Anka Niehof, Leontine Visser, "Feminisation of Agriculture as an Effect of Male Out-migration: Unexpected Outcomes from Jhapa District, Eastern Nepal", cit. p. 567.
} 
to access to opportunities while, on the contrary, the increasing presence of women's farmwork has been greatly related to indicators of poverty ${ }^{34}$ that demonstrate a negative relationship between women's livelihoods and the economic empowerment.

For this reason, it is worth focusing on the managerial aspect of feminizaton of agriculture to give sense to women's empowerment, which is considered in this study, as the women's ability to gain "more power and control over their own lives" 35 . In this sense, empowerment particularly addresses to women that were (and in some contexts are still today) traditionally disadvantaged compared to men in economic-cultural and political spheres. Therefore, empowerment would drive the process to reach gender equality, i.e. opportunities, responsibilities, access to resources and rights of individuals whether they are born male or female.

Some features of women's empowerment, as listed by the Guidelines of Women's Empowerment of the United Nations Population Fund (i.e. women's sense of self; right to determine choices; right to have access to resources; the ability to influence the direction of social change) ${ }^{36}$ could apply to the context of feminization of agriculture as indicators of land entitlement, women's participation in social groups, control over their mobility or voice in decisionmaking processes.

For this reason, some authors have affirmed that women's empowerment in agriculture "refers to increases in opportunities for women in a context in which norms dealing with access to or ownership of valuable resources and assets prevent or limit their participation"37 and this process would improve significantly

\footnotetext{
${ }^{34}$ Audrey Rowe, "The Feminization of Poverty: An Issue for the 90's", in Yale Journal of Law and Feminism, vol. 4, issue 1, 1991, p. 73-79.

${ }^{35}$ European Parliament, Directorate-General for Internal Policies, Women's Empowerment and Its Links to Sustainable Development, 2016, p.10, at < https://www.europarl.europa.eu/RegData/etudes/IDAN/2016/556927/IPOL_IDA(2016)556927_E N.pdf>. [Retrieved on 27 September, 2020].

36 UNFPA, Guidelines on Women's Empowerment for the UN President Coordination System, United Nations Population Fund, UN Population Division, Department of Economic and Social Affairs, 1995 , $<$ https://www.unfpa.org/sites/default/files/resourcepdf/Guidelines_complete_text_without_figures_296K.pdf>. [Retrieved on 27 September, 2020]. ${ }^{37}$ Ruth Meinzen - Dick, Agnes Quisumbing, Julia Biermayr-Jenzano, Vicki Wilde, Marco Noordeloos, Catherine Rgasa, Nienke Beintema, "Engendering Agricultural Research, Development, and Extension", in IFPRI Reseach Monograph, Washington, 2011, p. 11.
} 
if gender discrepancies were closed ${ }^{38}$ and resources, used in male headed households, were the same for women ${ }^{39}$.

In order to perceive the managerial side of feminization of agriculture as crucial for women's empowerment, and to analyze the way it entered the international law discourses, it is important to analyze the footprint of feminist and gender theories and the way they faced patriarchy, virilocality and patrilinearity that have traditionally characterized environmental and agricultural matters.

\section{Gender Theories on the Move}

When it comes to put "gender lens" 40 on agricultural questions, attention should be previously cast on the feminist analysis and critiques of the traditional economic models furthering gender inequalities and their proposal for a transformative agenda for women's empowerment.

Thus, it is important to question whether the open paths for feminist or gender perspectives into environmental issues ${ }^{41}$ could help frame the massive entry of women into agricultural labour and, more specifically, mitigate the negative aspects of feminization of agriculure. In other words, feminist reading of this socio-economic phenomenon could offer insights to lessen impaired welfare of women and overcome indisputable barriers concerning female workforce, especially in rural areas ${ }^{42}$. The study of feminist theories and their influences on environmental matters helps investigate the multiple aspects which animate feminization of agriculture and, ultimately, prompt the analysis to verify whether

\footnotetext{
${ }^{38}$ Alan de Brauw, Qiang Li, Liu Chengfang, Scott Rozelle and Linxiu Zhang, "Feminization of Agriculture in China? Myths Surrounding Women's Participating in Farming", in The China Quarterly, issue 194, 2008, p. 327-348.

${ }^{39}$ Menale Kassie, Jesper Stage, Hailemariam Teklewold, Olaf Erenstein, "Gendered Food Security in Rural Malawi: Why is Women's Food Security Status Lower?", in Food Security, vol.7, issue 6, 2015, p.1299-1320.

${ }^{40}$ Sandra L. Bem, The Lenses of Gender: Trasforming the Debate on Sexual Inequality, New Haven, Yale University Press, 1993.

41 Andrea J. Nightingale, "The Nature of Gender: Work, Gender, and Environment", in Environment and Planning D: Society and Space, vol. 24, issue 2, 2006, p. 165-185.

42 Liu Jia-cheng, Xu Zhi-gang, Zheng Qiu-fen, Lillian Hua, "Is the Feminization of Labour harmful to Agricultural Production? The Decision-making and Production Control Perspective", in Journal of Integrative Agriculture, vol. 18, issue. 6, 2019, p. 1392-1401.
} 
international environmental law had the ability to embody such perspectives to mitigate gender inequalities and the "crop gap" 43 .

Moreover, one should be aware of the fact that there are relevant, but not "unique", theoretical feminist-gender points of view influencing environmental ${ }^{44}$ law and this is the reason why the following sections discuss and outline different existing strands of thought, as they historically developed, and their relevant facets. Some feminist strategies simply asked to let women sit at the negotiating tables at national and international levels without facing the fact that such an endorsement did not necessarily mean recognition, effective empowerment and representation for women. As well pointed out by Cynthia Enloe, when "women are let in, it is because they have learnt to play masculine role and they do not threaten male political privilege" 45 .

This paper attempts to scrutinize the tangible efforts of feminist and gender studies ${ }^{46}$ to strengthen policies for the promotion of gender equality and women's acceptance in international environmental fora or instruments. The study does not aim at systematizing the gender outlook rather to explore indepth the perspectives brought by feminism to environmental and agricultural governance, their specificities and their contribution to the objective of international environmental treaties or soft law.

This study firstly traces historically and anthropologically the suggestions of women's literature and movements by linking them to the cultural order that has traditionally legitimated androcentric values, then it examines their readings of the nexus women-nature-society. Thus, the paper verifies whether, unlike and better than other socio-cultural theories, studies about women and environment were able to put theory into practice by considering women's existence in

\footnotetext{
${ }^{43}$ Maryellen Kennedy Duckett, "Empowering Female Farmers to Feed the World", in National Geographic, at <https://www.nationalgeographic.com/culture/article/partner-contentempowering-female-farmers $>$ [Retrieved on 12 September, 2020].

${ }^{44}$ Melissa Leach, Cathy Green, "Gender and Environmental History and Nature to Gender Analysis of Ecology and Politics", in Environment and History, issue 3, 1997, p. 343-370.

45 Cynthia H. Enloe, Does Khaki Become You? The Militarisation of Women's Lives, Pluto Press, London, 1983.

${ }^{46}$ Susan Buckingham, "Ecofeminism in the Twenty-First Century", in The Geographical Journal, vol. 170, issue 2, 2004, p. 146-154.
} 
relation with cultural and economic aspects of environmental matters and not simply in connection with biological cycles $^{47}$.

\subsection{Ecofeminism}

Ecofeminism, which emerged in the 1970s alongside the beginnings of the green political activism, has its roots in the conceptual framework of feminist thinkers and the term itself was coined by Françoise d'Eaubonne, who illustrated the potentialities of women to move an ecological revolution, in her book: "Le Féminisme ou la Mort" (1974) ${ }^{48}$. Despite its feminist vein, ecofeminism does not place women in the ruling position of power, rather it calls for a collaborative and connecting society ${ }^{49}$, avoiding the prevalence of a dominant group on one another ${ }^{50}$. Since that time many conceptual themes have been associated with this concept and several branches of ecofeminism developed, such as liberal ecofeminism, spiritual/cultural ecofeminism and socialist ecofeminism ${ }^{51}$. While this study does not aim at chronicling the history of ecofeminism and its articulations ${ }^{52}$, it is worth mentioning the features, main peculiarities and alternative voices that characterized this line of thought since, as suggested by Charlene Spretnak, ecofeminism has embodied at least three approaches: feminism, the left-green social ecology and the radical feminism ${ }^{53}$. To focus on its core aspects, ecofeminism conceptualizes the relationship of

\footnotetext{
${ }^{47}$ Lynda I.A. Birke and Gail Vines, "Beyond Nature Versus Nurture: Process and Biology in the Development of Gender", in Women's Studies International Forum, vol 10, issue 6, 1987, p. 555-570.

${ }^{48}$ Françoise D'Eaubonne, Le féminisme ou la mort, P. Horay, Paris, 1974; Susan Baker, "The Principles and Practice of Ecofeminism: A Review", in Journal of Gender Studies, vol. 2, issue 1, 1993, p. 4-26.

${ }^{49}$ Karen Warren, "The Power and the promise of Ecological feminism", in Environmental Ethics, vol. 12, issue 2, 1990, p. 125-146.

${ }^{50}$ Manuku Mukoni, "Gender Identity Construction, Community Environmental Education and Ecofeminism: Untapped Interconnections", in International Journal of Research and Innovation in Social Science, vol. 3, issue 7, 2019, p. 309-317.

51 George Metthew Nalunnakkal, Towards an Organic Womanism: New Countours of Ecofeminism in India, 2003, <https://www.elca.org/JLE/Articles/808>. [Retrieved on 12 September, 2020].

${ }^{52}$ Catherine Larrére, "La nature a-t-elle un genre? Variétés d'écoféminisme", in Cahiers $d u$ Genre, vol. 2 issue 59, 2015, p. 103-125.

${ }^{53}$ Charlene Spretnak, "Ecofeminism: Our Roots and Flowering", in Irene Diamond and Gloria Feman Orenstein (eds.), Reweaving the World: The Emergence of Feminism, Sierra Club Books, San Francisco, 1990, p. 3-14.
} 
women with nature by proposing the so called "feminine principle" 54 , which implies an inner and biological linkage between Mother Earth and women ${ }^{55}$. It has been said that "Nature herself is the experiment and women, as sylviculturalists, agriculturists and water resource managers, the traditional natural scientists" 56 and Maria Mies has precisely called women's work in producing sustenance "the generation of life" focusing on the so called "productive relationship" to explain that women not only collect and consume what has grown in nature but they make things grow ${ }^{57}$.

According to Mary Mellor, there is a strong linkage between women and the biological world and "ecofeminism is a movement that sees a connection between the exploitation and degradation of the natural world and the subordination and oppression of women" 58 so that environmental damages are linked to women's exploitation and lack of self-empowerment. On a different ground, some ecofeminists argue that women are closer to Nature than men because of a dominant androcentric paradigm that promotes dualism and relates women to earth and men to social life: a dualistic framework that reinforces oppression of women and Nature and favors men's control ${ }^{59}$.

Ecofeminism points out the relationship woman-nature by portraying the similarities between the renewed cycles of nature and the reproductive capacities of women's bodies and figures out a closeness that is not characterized by dominance or property schemes. The main assumptions of ecofeminism are the central role of women as mothers or nurturers of life and their natural vocation to respect, protect and take care of environment without claming exclusive rights or imposing enclosures so that women do not consider

${ }^{54}$ Cynthia Garrity-Bond, "Ecofeminist Epistemology in Vandana Shiva's the Feminin; The Principle of Prakriti and Ivone Gebara's Trinitaria Cosmology", in Feminist Theology, vol. 26, issue 2, 2018, p. 185-194.

${ }^{55}$ Chiara Corazza, "Il principio femminile/materno. La critica allo sviluppo di J.C. Kumarappa e V. Shiva", in Annalisa Zabonati (ed.), Ecofemminismo/Ecofeminsm, in Deportate, esuli, profughe. Rivista telematica di studi sulla memoria femminile, issue 20, 2012, p. 90-104.

56 Vandana Shiva, Staying Alive: Women, Ecology and Development, London, Zed Books, 1989, p.40.

${ }^{57}$ Maria Mies, Patriarchy and Accumulation on a World Scale, Zed Books, London, 1986, p. 1617.

${ }^{58}$ Mary Mellor, Feminism and Ecology, New York University Press, New York, 1997, p.1; Mary Mellor, "Women, Nature and the Social Construction of "Economic Men"', in Ecological Economics, vol. 20, issue 2, 1997, p. 129-140.

59 Tzeporah Berman, "The Raper of Mother Nature? Women in the Language of Environmental discourse", in Trumpeter, vol. 11, issue 14, 1994, p. 173-178. 
themselves as owners of the earth but they co-operate with biological resources to let grow and make grow. Ecofeminism also questions the pervasive androcentrism in the formulation of problems ${ }^{60}$, theories and concepts ${ }^{61}$ that reproduces a human-male centered approach towards nature (anthropocentrism) effectively marginalizing women's relevance in food production and women's attitude as custodians of the ecological systems (androcentrism).

However, the ecofeminist approach was strongly criticised and certain feminist movements argued the ecofeminist topic of "body-based argument" and underlined the way ecofeminist values of care, love, trust and reciprocity led to women's isolation and separation from social reality ${ }^{62}$. Moreover, the essential closeness to nature was censured by those activists and scholars who saw in many features of ecofeminism tools to reinforce the patriarchal ideology of domination ${ }^{63}$.

Then, ecofeminism was considered to be essentially static, unable to mirror women's needs in real life and simply focused on the inherent link between women and nature, women's responsibility as saviours and privileged carers without acknowledging the socio-economic and cultural changes concerning their position and role in society. As stated by these critical voices, the lack of a dynamic point of view misconsiders the so called "construction of gender"64, i.e. the fact that women have gained their social, political, cultural place in space and time through recent history.

Finally, ecofeminism was also chided for being "essentialistic in practice" 65 because of its basic assumption that women are naturally environmetalists and

\footnotetext{
60 This feature of ecofeminism was influenced by the "science question" in feminism. See Sandra Harding, The Science Question in Feminism, Cornell University Press, New York, 1986.

61 Bob Pease, "Recreating Men's Relationship with Nature: Toward a Profeminist Environmetalism", in Men and Masculinities, vol. 22, issue 1, 2019, p. 113-123.

62 Cecile Jackson, "Women/Nature or Gender/History? A Critique of Ecofeminist 'Development'”, in The Journal of Paesant Studies, vol. 20, issue 3, 1993, p. 389-418.

${ }^{63}$ Anne Archambault, A Critique of Ecofeminism, Canadian Woman Studies/Les cahiers de la femme, vol. 13 issue 3, 1993, p. 19-22.

64 Judith Lorber, Susan A. Farrell, The Social Construction of Gender, Sage Publications, Newbury Park, 1991.

${ }^{65}$ Kari Marie Norgaard, "The Essentialism of Ecofeminism and the Real", in Organization \& Environment, vol. 11 issue 4, 1998, p. 492-497; Elizabeth Carlassare, "Essentialism in Ecofeminist Discourse", in Carolyn Merchant (ed.), Ecology, Humanities Press, New York, 1994, p. 220-234.
} 
the Nature provides biologically the kind of resources nedeed to empower women in a sexist society ${ }^{66}$.

For these reasons and to escape from these critiques, the next generation of feminist movements broaden alliances, coalitions, networks, affinity groups and consensus and theories progressively abandon the original essentialism of ecofeminism to adopt a constructivist strategy ${ }^{67}$. The post-structuralists ${ }^{68}$ and the third wave feminist generation ${ }^{69}$ claim that the potentialities of the ecofeminist approach were not completely used and also charge ecofeminism by saying that it was not able to fruitfully face the injustices affecting women and the gendered oriented mainstream which attributed to nature the ratio of naturalized social inequalities.

However, these critiques are not shared by the entire feminist literature.

As registered by Noël Sturgeon:

"certain essentialist moments in ecofeminism [...] are part of creating a shifting and strategic identification of the relation between 'women' and 'nature' that has political purposes: it [ecofemism] creates unity between very different kinds of women; it justifies a feminist critique of environmentalists; and it solidifies connections among feminism(s), partecipatory democratic structures, and nonviolent direct action"70.

Indeed, early ecofeminism contributed to give birth to women's environmental movements like Chipko in India, the Green Belt Movement in Kenya and Love Canal in New York State pointing out women's vulnerability to environmetal damage and their struggle to resist environmental destruction ${ }^{71}$. Others argue that charges against ecofeminist were disproven and the value of ecofeminism

66 Vivian Gornick, Barbara K. Moran (eds.), Woman in Sexist Society: Studies in Power and Powerlessness, Basic Books, 1971, New York; Marti Kheel, Nature Ethics: An Ecofeminist Perspective, Rowman \& Littlefield Publishers, Lanham/Boulder/New York/Toronto/ Plymouth, 2008, p. 8

67 Diana Fuss, Essentially Speaking: Feminism, Nature \& Difference, Routledge, New York/London, 1989; For a deep analysis see Carlo Focarelli, Costruttivismo giuridico e giurisdizioni internazionali, Kluwer/Cedam, 2019, Milano.

68 Verena Andermatt Conley, Ecopolitics. The Environment in Poststructuralist Thought, Routledge, London/New York, 1997.

${ }^{69}$ Niamh Moore, "Ecofeminism and Third Wave Feminism? Essentialism, Activism and the Academy", in Stacy Gillis, Gillian Howie and Rebecca Munford (eds.), Third Wave Feminism. A Critical Exploration, Palgrave MacMillan, New York, p. 227-239.

${ }^{70}$ Noël Sturgeon, Ecofeminist Nature: Race, Gender, Feminist Theory and Political Action, Routledge Taylor \& Franscis, London/New York, 1997. p. 11.

${ }^{71}$ Bettina B. Bock, Sally Shortall, (eds.), Rural Gender Relations: Issues and Case Studies, Cabi Publishing, Cambridge, 2006, p. 290. 
should have been conceived under a structuralist point of view ${ }^{72}$. To sum up, it is possible to say that ecofeminism was a "melting pot" including a huge variety of divergent approaches both "essentialists" and "militants" in socio-economic spheres $^{73}$. Discrediting one single aspect of ecofeminism would mean misinterpreting a complex "body" of thought ${ }^{74}$ to give a partial image of the overall picture ${ }^{75}$.

\subsection{Women and the Environment}

It has been said that "if feminism wants to maintain its international vocation, it must also think in environmentalist terms" ${ }^{76}$. The women and environment strand of thought rises in the mid-1980s when the relationship between women and the environment is perceived in a non-static sense and women's contribution get into the contexts of environmental sustainability and environmental justice ${ }^{77}$. Taking into account studies on day-to-day lives and concerns of women, this approach calls for project and programmes putting at first women's perspectives as individuals or members of groups, their involvement in protecting environment and inborn sense of responsibility in maintaining a balance between human needs and the earth's resources ${ }^{78}$.

Assuming that women's altruism (as stressed by ecofeminism) was a symptom of women powerlessness, reproducing their lying behind the work and social rules imposed by men, the women and environment approach stresses their

\footnotetext{
72 Greta Gaard, "Ecofeminism Revisited: Rejecting Essentialism and Re-Placing Species in a Material Feminist Enviornmentalism", in Feminist Formations, vol. 23, issue 2, 2011, p. 26-53.

73 Jytte Nhanenge (ed), Ecofeminsm. Towards Integrating the Concerns of Women, Poor People, and Nature into Development, University Press of America, Maryland, 2011.

${ }^{74}$ Elizabeth Mayer, The Power and the Premise of Ecofeminism, Reconsidered, in Honors Research Project, 1994, at $<$ https://digitalcommons.iwu.edu/cgi/viewcontent.cgi?article=1007\&context=phil_honproj>.

[Retrieved on 28 September, 2020].

${ }^{75}$ In the following sections the term ecofeminism gathers the multiple variations of this point of view both its spiritual versions, social and moral forms and critiques.

${ }^{76}$ Alicia H. Puleo, "What is Ecofeminism", in Quaderns de la Mediterrania, 2017, vol. 25, p. 2734, at p. 32.

77 Greta Gaard "Ecofeminism Revisited: Rejecting Essentialism and Re-Placing Species in a Material Feminist Environmentalism", cit., p. 26.

${ }^{78}$ Some distinguished women and environment from women in development, this latter one being a different academic and theretical branch of the approach.
} 
being daily administrators of biological resources and best placed to face ecological risks ${ }^{79}$.

Women become agents both in developed and developing countries: in the industrialized Global North, they are involved in evironmental policies concerning issues such as pollution ${ }^{80}$, unequal distribution of resources and misappropriation of green areas whereas in the Global South they mainly put attention on their poor condition in rural areas ${ }^{81}$.

Despite this, the introduction of a "female share" in programmes dealing with environmental problems shows positive and negative aspects: on the one hand it surely serves to take into consideration the complex situation of women and their being both valuable social voices to be involved and those most afflicted by environmental risks. On the other hand such a recognition means nothing without proper investments in education or vocational learning for women. What is more, the focus on women's experiences (e.g. isolation, gender injustice, illiteracy) and risks isolates them by putting their lives apart from modern economic trends and does not stimulate fair interdependence between sexes in facing social and environmental changes. In this sense, this approach reproduces the image of women holding a subordinated position, the same that they occupied in androcentric society criticised by ecofeminism because of the masculin system of powers. Women still play sidelines the men-made schemes, at the corner of the market systems, and no significant actions are suggested to enforce their value in production, distribution and sharing of resources.

Another tricky point of this approach lies in the assumption that a single homogeneous category of "woman" represents all women without any distinction based on their quality of life, social status, lifestyles and most importantly the relationship with men. As said by Cecile Jackson "women as a group do not experience environmental degradation in a uniform manner -

\footnotetext{
${ }^{79}$ Anne E. Simon, "Whose Move? Breaking the Stalemate in Feminist and Environemental Activism", in UCLA Women's Law Journal, 1992, vol. 2, p.145-164.

80 An example of western woman activist is Rachel Carson, Silent Spring, Mariner Books, Boston/New York, 2002.

${ }^{81}$ Bernadette P. Resurrección, "Gender and Environment from 'Women, Environment and Development' to Feminist Political Ecology, in Mac Gregory Sherilyn (ed.), Routledge Handbook of Gender and Environment, Routledge, Oxon, 2017, p. 71-85.
} 
these effects are mediated by the livelihood system" 82 and, in fact, inequalities among women exist in household level, access to resources and decision making powers ${ }^{83}$. In this sense, the analyzed approach pretends to portray the universalism of women's conditions that does not exist while as suggested by Beverly Skeggs the sign of success of the feminist thought is in its diversification and its ability to underline how various systems of domination intersect with gender ${ }^{84}$.

\subsection{Gender, Environment and Sustainable Development}

The importance gained by the gender analysis into development in 90 s gives to the supporters of the women in development approach ${ }^{85}$ the necessary impetus to handle women's issues through a gender paradigm ${ }^{86}$. Differently from the previous women and environment approach, which voiced the "genetic" exclusion of women as individuals, the gender, environment and sustainable development movements stress the importance of a gender reading of policies and laws by affirming that the gender gap is the result of a social contruction of roles and behaviours. This approach actually distinguishes "sex" from "gender" and frames women's exclusion as the result of social artifacts not the direct product of biological essentialism ${ }^{87}$.

But, at a closer look, the gender approach does not only serve to show inequality in social, cultural and economic fields rather it tackles ecological questions and the ways environmental problems are differently overcome by multiple realities of women.

\footnotetext{
${ }^{82}$ Cecile Jackson, "Doing What Comes Naturally? Women and Environment in Development", in World Development, 1993, p.1949

83 Ibidem.

${ }^{84}$ Beverly Skeggs, Formations of Class \& Gender. Becoming Respectable, SAGE Publications, London, 1997.

85 Gina Koczberski, "Women in Development: A Critical Analysis", in Third World Quarterly, vol 19 , issue 3, 1998, p. 395-410.

${ }^{86}$ Rosi Braidotti, Ewa Charkiewicz, Sabine Häusler, Saskia Wieringa, Women, the Environment and Sustainable Development. Towards a Theoretical Synthesis, Zed Books, London, 1994; Sabine Hausler, "Gender and the Environment: Recent Initiatives to Improve Sustainable Development Policy, Planning and Practice", in Gender, Technology and Development, vol. 1, issue 3, 1997, p. 327-348;

${ }^{87}$ For a thorough analysis of the relationship "sex" and "gender" see Liz Stanley, "Should 'Sex' Really $\mathrm{Be}$ 'Gender' - or 'Gender' Really Be 'Sex"', in Stevi Jackson and Sue Scott (eds.) Gender: A Sociological Reader, Routledge, London/New York, 2002, p. 31-41.
} 
Women are seen in their relationship with men and the differences inside the "women category" are generated by legal status, lifestyles, class and ethnicity, control of resources they managed ${ }^{88}$. In this sense, taking into consideration agriculture, the allocation of resources, the reproductive work and responsibilities not only reproduce the division of labour and powers by and between sexes rather they operate differently on the basis of social, cultural and economic identities. Women working off-farm as wage workers have more control over wages and have more power in household decision-making; differently, women who work as family workers are less likely to increase their status, they are unremunerated and lack of decision-making powers. Another relevant distinction exists between single women and mothers in wage work: the former generally escape household work while the latter are never relived from their traditional responsibilities which are not assumed by men. This implies that when mothers are away at work their household work is taken over by daugthers that are pulled out of school in order to replace their mothers and take care of siblings ${ }^{89}$. In these cases women have the compounded burden of productive and reproductive work.

Male-female and female-female relationships interact with environmental patterns and influence powers in decision-making processes for the achievement of development, this latter one to be understood as "sustainable" at a global and local level: the gender factor influences the way resources are managed at a regional level but it also routes global plans and trends in environmental matters. For example, recognizing the importance of women's labour in local countryside may lead to integrate women's traditional knowledge and approach towards environment in the elaboration of global plans and strategies for reforestation, control of erosion of genetic resources and use of pesticides. In fact, women are able to provide a friendly approach to nature

\footnotetext{
${ }^{88}$ Considering the situation of migrant women, see Letizia Palumbo, Alessandra Sciurba, The Vulnerability to Exploitation of Women Migrant Workers in Agriculture in the EU: the Need for a Human Rights and Gender Based Approach, 2018, at $<$ https://www.europarl.europa.eu/RegData/etudes/STUD/2018/604966/IPOL_STU(2018)604966 EN.pdf>. [Retrieved on 28 September, 2020].

$\overline{89}$ See Susana Lastarria-Cornhiel, Feminization of Agriculture: Trends and Driving Forces, Background Paper For the World Development Report 2008, cit, at p. 12.
} 
while fostering sustainable development practices and ecological service policies $^{90}$.

The gender, environment and sustainable development point of view gathers people, their gender and roles so that women are not just viewed as victims or persons in need rather, they are seen as recipients, participants and decision makers, together with men.

Moreover, the protective attitude towards women as vulnerables gives way to a claim for the expansion of women's experience, skills and creativity and under this point of view women, as representatives of half of the population, are not "special interest groups" rather a leading force eager to guide macro development claims in sustainable use of biological diversity, fight against food scarcity, call for green energy and environemenal justice in urban spaces. While demanding for gender equity, women also contribute to a development which is gender-aware and sustainable, i.e. women negotiate the inclusion of gender relations and sustainability in economy to create a different economic paradigm.

Despite the above mentioned features and advancements of the approach, it is worth mentioning the complexities that lie behind the gender, environment and sustainable development line of thought, i.e. the definition and contents of sustainable development suitable for women ${ }^{91}$ and the mechanisms to guarantee equality between men and women and among women.

Development has been tipically evaluated in terms of efficiency and maximization in the utilization of resources, but women's contribution has radically altered the discourse on development by giving a peculiar reading of its adjectivation as "sustainable". According to Wendy Harcourt sustainable development for women implies "conversations between subjects rather than studies of objects" and it is a strategy to empower those "subjugated by oppresive practices" to negotiate "workable solutions to the environment and development crisis"92.

\footnotetext{
90 Patricia E. Perkins, "Feminist Ecological Economics and Sustainability", in Journal of Bioeconomics, vol. 9, issue 3, 2007, p. 227-244.

${ }^{91}$ Cecile Jackson, Ruth Pearson (ed.), Feminist Visions of Development: Gender Analysis and Policy, Routledge, London/New York, 1998.

${ }^{92}$ Wendy Harcourt (ed.), Feminist Perspectives on Sustainable Development, Zed Books LTD, London/New Jersey, 1994, p.22
} 
Women no longer deal with development matters by focusing narrowly on efficient industrialization, exports and savings, but they complain the sterile measures without realist and economic goals. The activism of women gendered the concept of human development routing it through sustainable use of resources $^{93}$ : as said by Gita Sen (of Development Alternatives with Women for a New Era - DAWN) development implies synergies ${ }^{94}$ such as the socially responsible management and use of resources, the elimination of gender subordination and social inequality and the organizational restructuring that can bring these about" ${ }^{95}$. To make the linkage women-sustainable development effective, policy actions should redress the disproportionate impact of economic strategies, social and environmental shocks and stresses on women and girls.

Referring to the methods and strategies, it has been said that the "warm and cuddly" strategy could be not viable to really seek to close the gender gap ${ }^{96}$ and, ultimately, the fit-for-all policy to tackle the differencies among women in agriculture appears to be useless, unless it adopts the same criteria for economic and social sustainability or the same regulations governing access to and control over resources used in production. Indeed, the search for a uniform strategy has always been a critical point for feminist scholars since it implies that the agricultural sector has reached everywhere the same, higher stage of development and women share the common identity and experience of male oppression.

On the contrary, women living in farming contexts or in rural communities would be reluctant to identify themselves with the same feminist identity of urban

\footnotetext{
${ }^{93}$ Vidhu Verma, "Engendering Development: Limits of Feminist Theories and Justice", in Economic and Political Weekly, vol. 39, issue 49, 2004, p. 5246-5252.

${ }^{94}$ Gita Sen, Cecilia Alemany, "SDG5 Advancing Women's Rights and Strengthening Global Governance: The Synergies", extract from the civil society report Stotlight on Sustainable Development 2019, at https://dawnnet.org/wpcontent/uploads/2019/07/Spotlight_Innenteil_2019_web_sdg5.pdf, [Retrieved on 30 September, 2020].

${ }^{95}$ Jane L. Parpart, M. Patricia Connely, and V. Eudine Barriteau (eds.), Theoretical perspectives on Gender and Development, International Development Research Centre, Canada, 2000, at < https://prd-idrc.azureedge.net/sites/default/files/openebooks/272-

4/index.html\#page_161>.[Retrieved on 27 September 2020]

${ }^{96}$ Alexandra Stephens, Gender Issues in Agriculture and Rural Development Policy in Asia and the Pacific, FAO Regional Expert Consultation, 1995, at <http://www.fao.org/3/x0177e00.htm>. [Retrieved on 28 September, 2020].
} 
women ${ }^{97}$ and they would reject to be labelled in the same way because of their various perceptions of "the question of equality with men, the injustice and the underrepresentation of women in farm industry"98.

\section{From Theories to Practice: Greening Women in International Law}

The above mentioned theoretical moments of recognition of women's role and the efforts to foster a feminist point of view prompt this study to investigate whether the outcomes of such an activism and engagement have influenced international environmental law and more specifically agricultural policies since their rising in the public debate. The main questions to be answered to deeply scrutiny the relationship between gender-environment theories and international environmental law are:

- Have these theories abandoned their idealistic and static contexts to be transformed into policy implementation at the international and national level?

- Do feminist insights incrementally reform the substantive gender inequality discourse making it seriously taken into consideration by international environmental law treaties?

- Do feminist approaches touch areas of international law currently resistant to feminist analysis to let women receive more attention? If not, Do they create modest changes without disrupting the structures and institutions of international law?

- Do the above mentioned theories lead to design an international system dealing with women's empowerment in crucial sectors such as agriculture?

The following sections aim at answering these questions by giving an overview of the feminist progressive influence on the values and assumptions that inform

\footnotetext{
97 Berith Brandth, "On the Relationship Between Feminism and Farm Women", in Agriculture and Human Values, vol.19, issue 2, 2002, p.107-117.

98 Ibidem, p. 108. Also see Berith Brandth, "Changing Femininity The Social Construction of Women Farmers in Norway", in Sociologia Ruralis. Journal of the European Society for Rural Sociology, vol. 34, issues 2-3, 1994, p.127-149.
} 
international environmental law and how feminist paradigms are pertinent and consistent with this branch of law ${ }^{99}$.

Christopher C. Joyner and George E. Littles were both skeptical on the relationship between feminist approaches and international environmental law and doubtful about the impact of the gender activism on the contemporary international environmental law. They say that "feminist legal scholars have not yet devoted considerable conceptual attention on environmental law" 100 and also Robert M. Verchick remarked that "no law review article has formally explored environmental justice within the context of feminist theory"101. On the contrary Anne E. Simon explored the international dimensions of feminist and ecological activism focusing on the consequences of a feminist perspective in environmental law both nationally and internationally ${ }^{102}$. At a deeper scrutiny, it is possible to affirm that the introduction of feminist and gender-environment approaches into policy applications was a complex and thorny process. But, the women-gender growing literature and feminist movements made an intense struggle to let questions on inequalities between and among sexes emerge in international fora. They provided material basis for framing women's conditions in concrete terms, whether women would be considered as victims or as actors $^{103}$.

Hence, the feminist point of view has entered recently the international environmental field: contemporary international environmental law was generally considered to be grounded on an androcentric perspective so that the knowledge of ecosystem and conservation practices held by women, together with their rights and interests, were largely misconsidered and even marginalized.

\footnotetext{
99 Vakoch A. Douglas, Sam Mickey (eds.), Ecofeminism in Dialogue, Lexington Books, Lanham/Boulder/New York/London, 2018.

${ }^{100}$ Christopher C. Joyner, George E. Little, "It's Not Nice to Fool Mother Nature! The Mystique of Feminist Approaches to International Environmental Law", in Boston University International Law Journal, vol. 14, 1996, p. 223-266.

${ }^{101}$ Robert R.M. Verchick, "In a Greener Voice: Feminist Theory and Environmental Justice", in Harvard Women's Law Journal, vol. 19, 1996, p. 23-88.

${ }^{102}$ Anne E. Simon, "Whose Move? Breaking the Stalemate in Feminist and Environmental Activism", cit. p. 149.

${ }^{103}$ Bina Agarwal, "The Gender and Environmental Debate: Lessons from India", in Feminist Studies, vol.18, issue 1,1992, p. 119-158.
} 
Main evidence of this is the Declaration of the United Nations Conference on the Human Environment (or Stockholm Declaration) ${ }^{104}$ which never mentioned women and it only reffered to men to indicate "human beings". This androcentric fil-rouge is envisaged by Val Plumwood who underlines the (West) masculin preponderance in Principle 21 which uses a dualism in describing the relationship human/nature 105 instead of the "togetherness" approach of ecofeminism ${ }^{106}$. Ann J. Tickner also argues that international relations have always been based upon the experiences and ideas of men and the realm of international law has registered a disparity between the number of men and women involved in world politics ${ }^{107}$.

In the same way, Marilyn Waring criticizes the global economic system as it emerged from the reading of the Rio Declaration for not evaluating women caring for environment and their unpaid work in the production of goods and services for consumption and market ${ }^{108}$.

In the following years ecofeminism and its concerns for equality between sexes illuminated many area of international law, among these international environmental law ${ }^{109}$, and the diverse array of ecofeminist opinions and experiences converged into the narrative asking for a rethinking of the ethical foundation of environmental regulations.

The first attempt of ecofeminist defence of the Earth took place at the World Conference to Review and Appraise the Achievements of the United Nations Decade for Women: Equality, Development and Peace, held in Nairobi, in 1985 (following referred to as Nairobi Conference) ${ }^{110}$ which helped to focus on the relationship between women and nature and asked for the recognition of

\footnotetext{
104 United Nations, The United Nations Conference on the Human Environment, June , 1972, UN Doc. A/CONF.48/14/Rev. 1.

105 Ibidem, Principle 21: "States have [...] the sovereign right to exploit their own resources pursuant to their own environmental policies [...]", at p. 5.

${ }_{106}$ Val Plumwood, Feminism and the Mastery of Nature, London, Routledge, 1993.

${ }^{107}$ Ann J. Tickner, Gender in International Relations: Feminist Perspectives on Achieving Global Security, Columbia University Press, New York, 1992.

108 Marylin Waring, If Women Counted: A New Feminist Economics, Harper \& Row, New York, 1988.

${ }^{109}$ Hilary Charlesworth, Christine Chinkin, Shelley Wright, "Feminist Aproaches to International Law", The American Journal of International Law, vol. 85, issue 4, 1991, p. 613-645.

110 United Nations, Report of the World Conference to Review and Appraise the Achievements of the United Nations Decade for Women: Equality, Developmnet and Peace, Nairobi 15-26 July 1985, UN Doc. A/CONF.116/28/Rev. 1.
} 
women's key role in protecting the planet and its natural resources. Moreover, the Nairobi Conference highlighted some "area of special concern" 111 and promoted the implementation of programmes to "ensure ample access for them [women] to the means of production, processing and preservation techniques"112.

Ecofeminists like Vandana Shiva and Maria Mies also raised their voices to denounce the concept of "development" as embodied by the 1986 United Nation Declaration on the Right to Development, saying that it constituted another colonialism ${ }^{113}$ by perpetuating exploitation, profit maximization and accumulation. According to Shiva it created new "colonies": the South, Nature and Women ${ }^{114}$. These critiques served to highlight that the Declaration's provisions provided equality and opportunity for women in theory, but factually they did little to limit discrimination against women and ignored the realities of their conditions.

Ecofeminism intertwined the woman and environment approach at the World Women's Congress for a Healthy Planet ${ }^{115}$ where an exploration of women's daily problems and material contraints were introduced to the international community ${ }^{116}$.

Following this storyline in international fora, feminist concerns and principles inspired the Women's Action Agenda for the 1992 UN Conference on Environment and Development in Rio de Janeiro ${ }^{117}$ which was hailed as the

\footnotetext{
111 Ibidem, Chapter IV, paras, 277-304.

112 Karen Maters, The Nairobi World Conference, Women of Europe Supplement No. 24, Commission of the European Communities, Directorate-General Information, Communication, Culture Women's Information Service, 1986, p. 41, at <http://aei.pitt.edu/33993/1/A470.pdf>. [Retrieved on 28 September 2020].

${ }_{113}$ Vandana Shiva, Staying Alive: Women, Ecology and Development, cit. p. 2.; Vandana Shiva, Maria Mies, Ecofeminism, Zed Books, London, 2014.

114 Vandana Shiva, Biopiracy: The Plunder of Nature and Knowledge, South and Press, Bostosn, 1997.

${ }^{115}$ The World Women's Congress for a Healthy Planet, Miami Florida, November 8-12, 1991. The event gathered more than 1500 women from over 80 countris to discuss their vision of a healthy planet and assure women's participation in the 1992 United Nations Conference on Environment and Development (UNCED) IN rio de Janeiro Brazil in 1992.

${ }_{116}$ Noël Sturgeon, "Ecofeminist Natures and Transnational Environmental Politics", in Heather Eaton, Lois Ann Lorentzen (eds.) Ecofeminsm and Globalization: Exploring Culture, Context, and Religion, Rowman \& Littlefield Publishers, New York/Toronto/Oxford, 2003, p. 91-122.

117 United Nations Conference on Environment and Development, Rio de Janeiro, Brazil, 3-14 June 1992.
} 
entry point of (eco)feminism into the UN Conference on Global Environment ${ }^{118}$. The ecofeminist influence on the Healthy Planet Congress emerged in the ideological approach of the Agenda 21 that recorded the ethical position of ecofeminism by proposing a participatory plan for women on equal footing with men and the universal access to information. Ecofeminist theories and claims became instrumental in creating alliances to rise a collective feminist struggle from developed as well as developing countries, and an example of this is represented by the Chipko indigenous women's protection of trees from the threat of massive logging in India ${ }^{119}$.

The ecofeminist spiritual-cultural and ontological approach headed towards more realistic assumptions at the UN Conference on Women in Beijing ${ }^{120}$ (1995) whose platform "Women and Environment"121 was the crucial area of concerns: it served to introduce the gender mainstreaming in development process and countries, which joined the Conference, agreed to implement policies to include women in decision making processes or to adopt laws to maintain women-men balance in productive sectors ${ }^{122}$.

Despite the Beijing Conference and the efforts made by international instruments to turn the socio-economic paradigm into an activist plan, women entered international environmental law as victims, particularly as persons in need of protection: as demonstrated by the Declaration of Santa Cruz de la Sierra and Plan of Action for the Sustainable Development of the Americas, women were treated as a "vulnerable group"123. Many aspects of the women's active involvement in promoting environmental ethic (e.g. their effort to minimize waste or avoid excessive consumption of natural resources) were mentioned,

\footnotetext{
118 The Agenda 21 for Women's Action is a document about the interrelated issues of women and environmental stability and it mirrors the disequalities and difficulties of women's situation in many sectors. See Willis Jenkins, Whitney Bauman (eds.), The Spirit of Sustainability, Berkshire Publishing Group, Massachussetts, 2010, p. 172.

${ }^{119}$ Bernadette P. Resurrección, "Persistent Women and Environmental Linkages in Climate Change and Sustainable Development Agendas", in Women's Studies International Forum, 2013, p. 33-43.

120 United Nations Fourth World Conference on Women, Beijing , China, September 1995.

121 United Nations, Report of the Fourth World Conference on Women, Beijing , 4-15 September 1995, UN Doc. A/CONF.177/20/Rev. 1, par. 246.

122 Radha Wagle, Soma Pillay, Wendy Wright, Feminist Institutionalism and Gendered Bureaucracies: Forestry Governance in Nepal, Palgrave Macmillan, Singapore, 2020.

${ }^{123}$ Declaration of Santa Cruz de la Sierra and Plan of Action for the Sustainable Development of the Americas, Santa Cruz de la Sierra, Bolivia, 7 December 1996, at http://www.cumbreamericas.org/summit_sd/summit_sd_dec_en.pdf. [Retrieved on 29 September, 2020].
} 
but the traditional "official" role of women "as mothers in need" remained central.

A more comprehensive scenery emerged from the Johannesburg Declaration on Sustainable Development ${ }^{124}$ whose commitment was to ensure "that women's empowerment and emancipation, and gender equality are integrated in all activites encompassed within Agenda 21"125: the Johannesburg Plan of Implementation (following referred to as the Plan) variously mentioned women to indicate that the gender-environmental outlook and sustainable development entered the scene of international environmental law and "the outcomes of the Summit should benefit all, particularly women"126. The Plan also embodied gender-sensitive considerations into the means of implementation namely education, data collection, public participation and decision making.

This trend continued up to 2015 when the United Nations released the Sustainable Development Goals ${ }^{127}$ which also involved the Women's Major Group, a network of feminist organizations promoting rights and gender equality and affiliate organizations (such as Women Environmental Programme, Forum of Women's, NGOs of Kyrgyzstan, Asia Pacific Forum on Women, International Women's Health Coalition and Law and Development). The Sustainable Development Goals addressed gender and women's rights and included mention of gender in several goals meaning that women's prerogatives are not "indipendent silos" to be tackled separately rather cross-cutting issues in gender policies ${ }^{128}$. However the ecofeminist and gender approaches embodied by the Sustainable Development Goals did not avoid feminist critiques dued to failures to structural reformation and main concerns related to Goal $5^{129}$. This Goal was criticized not to appropriately acknowledge, "or even attempt to understand,

\footnotetext{
124 United Nations, Report of the World Summit on Sustainable Development, Johannesburg, South Africa, 26 August- 4 September 2002, UN Doc. A/CONF.199/20.

125 Ibidem, par. 20.

${ }^{126}$ United Nations, Plan of Implementation of the World Summit on Sustainable Developmment, 4 September 2002, UN Doc. A/CONF.199/20, par. 3.

127 United Nations, Transforming Our World: The 2030 Agenda for Sustainable Development, 21 October 2015, UN Doc. A/RES/70/1.

${ }^{128}$ Karen Morrow, "Gender and the Sustainable Development Goals", in Duncan French and Louis J. Kotzé (eds.), Sustainable Development Goals, Edward Elgar Publishing, Cheltenham, 2018, p. 149-172.

129 United Nations, Transforming Our World: The 2030 Agenda for Sustainable Development, cit., Goal 5 "Achieve Gender Equality and Empower All Women and Girls".
} 
structural power relations" (i.e. it does not fully consider the pervasive gender wage gaps and occupational divide between women and men) and this deficiency creates "an inadequate framework for recognizing hierarchies of gender, class, region, or level of development". ${ }^{130}$.

To sum up, women's involvement, which ask for gender equity and equality, was troublesome in global environmental agenda because of two main factors: the barrier of the traditional male nature of the international system, and the critiques issued by feminist movements. In fact, the traditional international environmental law relations and diplomacy were unwilling to give women a seat at the international negotiations and once allowed it limitied itself to embody the image of women as "subjects in need".

On the other hand, while it is certainly true that women's action succedeed to be effective because of the organizations and alliences of certain feminist groups it must be also said that problems related to differences between women remained muted and the existence of a global sisterhood crashed through the claims of minority groups of women (women of colour, women of different sexual orientation or with disabilities) which put at front peculiarities of race, class and other social discrepancies to criticise the unilateral approach ${ }^{131}$. This also implied a "misrepresentation" problem because women put into main conferences failed to represent diverse voices of peasants, rural and indigenous women whose struggles and ethnic remained tactically apart ${ }^{132}$.

In conclusion, the entry point of women's voice into the international fora brought many problematic issues such as that of representation, advocacy and construction of identities. Women, being both subjects and objects of law, joined the public sphere of the international environmental system, but they were incorporeted as a one single category, the easiest to control and manage by the techno-burocratic structures. As said by Sara Smith:

\footnotetext{
${ }^{130}$ Consortium on Gender, Security \& Human Rights, Feminist Critiques of the Sustainable Development Goals. Analysis and Bibliography, 2017, at https://genderandsecurity.org/sites/default/files/Feminist_Critiques_of_the_SDGs_-

Analysis_and_Bibliography___CGSHR.pdf, p. 5, [Retrieved on 30 September, 2020].

${ }_{131}$ See Astrid Henry, Not My Mothers' Sister. Generational Conflict and the Third - Wave Feminism, Indiana University Press, Boolongton and Indianapolis, 2004.

132 Irene Dankelman, "Women Advocationg for Sustainable Livelihoods and Gender Equality on the global Stage", in Wendy Harcourt (ed.), Women Reclaiming Sustainable Livelihoods: Spaces Lost, Spaces Gained, Palgrave MacMillan, New York, 2012, p. 21-41.
} 
"If women are assumed to be victims rather than actors or as peaceful rather than aggressive or as existing in the domestic or private realm (rather than the public sphere) then their experience and perspectives on global politics are more easily ignored and justified as marginal"133.

In fact, such a construction of gender is evidence of inequality and it has contributed to the exclusion of women from international relations ${ }^{134}$ until recent.

\section{Mapping the Rumors of Feminization of Agriculture within International Environmental Law}

"In my own country of Zimbabwe, women in most of the rural areas are the main producers-growing food not only for their families but for sale. Often, they must do this alone, for their husband and sons have left home for the cities or the mines. [...] International agencies and governments have everywhere ignored the vital part that women play in caring for the environment. Their voice, like their knowledge and experience, is simply not heard"135.

This quotation does not only describe some of the main features of the feminization of agriculture trend, as outlined in the first section of this paper, but it also suggests the little attention put on this phenomenon by international and national law systems.

Ecofeminism, women and gender approaches offered new emerging issues to theorize the relationship women-environment while dealing with the feminization of agriculture, e.g. privatization of water and women's access to water, women's involvement as citizens in decision-making processes concerning agriculture, gender and agricultural development, the genderedness of rural policy and new organizations of rural women for environmental sustainability ${ }^{136}$. More recently

\footnotetext{
${ }^{133}$ Sarah Smith, "Introducing Feminism in International Relations Theory", in E- international Relations, 2018, at <https://www.e-ir.info/2018/01/04/feminism-in-international-relationstheory/>. [Retroeved on 30 September, 2020].

134 Jill Steans, Gender and International Relations. Theory, Practice, Policy, Polity Press, Cambridge, 2013.

${ }_{135}$ Irene Dankelman and Joan Davidson, Women and Environment in the ThirdWorld: Alliance for the Future, Earthscan Publications, London, 2004, Foreword, p. IX.

${ }^{136}$ Bettina B. Book, Sally Shortall (eds.), Rural Gender Relations: Issues and Case Studies, CABI Publishing, Oxford/Cambridge, 2006.
} 
feminist literature dealt with the broader category of rural women which includes female farmers, peasant or indigenous women and the variety of their life experiences $^{137}$.

Feminist-environmental interests continue to push for changes and highlight that, despite labour feminization, women are manifestly under-represented in leadership positions in agriculture and their participation and empowerment are so low ${ }^{138}$. International instruments show the progressist attempts of the United Nations System and civil society to implement the outcomes of the already mentioned conferences, summits and soft law instruments for the recognition of women's rights in agriculture and their role in agro-food sectors. An analysis of the international agenda shows the gradual assimilation of women and gender theories by international instruments that guarantee rights for rural women and girls and the fostering for their empowerment.

The Rural Workers's Organizations Convention (No. 141, 1975) ${ }^{139}$ foresaw the need to recognize the challenges faced by women and focused on the roles that women play in rural community to underline the importance of equal access to education and training activities ${ }^{140}$. This would have served to promote women's entrepreneurship and productive employment because, as said by Katherine Jellison women "preferred their productive roles on and off the farm to the domestic ones [...] they valued their work as farm producers and for reasons of economics and family politics wanted to retain that position"141.

While the Convention on the Elimination of all Forms of Discrimination Against Women (following Cedaw) ${ }^{142}$ is considered to be the main product of feminism activism in international arena ${ }^{143}$, its art. 14 can be viewed as the first translation of ecofeminism and the women and environment approach in

\footnotetext{
137 Barbara Pini, Berit Brandth, Jo Little, (eds), Feminisms and Ruralities, Lexinton Books, Lanham/Boulder/ New York/ London, 2015.

${ }^{138}$ Margaret Alston, Breaking Through the Grass Ceiling. Women, Power and Leadership in Agricultural Organisations, Harwood Academic Publishers, Amsterdam, 2000.

139 International Labour Organization, Rural Workers' Organizations Convention, 1975 (No.141).

140 Ibidem, Appendix, par. 14 lett. $c$ ).

141 Katherine Jellison, Entitled to Power: Farm Women and Technology, 1913-1963, The University of North Carolina Press, 1993.

142 United Nations, Convention on the Elimination of All Forms of Discrimination Against Women, 18 December 1979, 1249 UNTS 13.

${ }^{143}$ Marta R. Vanegas, Lisa R. Pruitt, "Cedaw and Rural Development: Empowering Women with Law from the Top Down, Activism from the Bottom Up", in University of Baltimore Law Review, vol. 41 , issue 2,2012 , p. 263-320.
} 
agriculture: it addresses specifically to rural women ${ }^{144}$ and entitles them with a vast array of rights related to agriculture and development (e.g education, health, care, civil and political rights) ${ }^{145}$.

Cedaw describes women in agriculture as members of a disadvantaged group in need and reserves to rural women the "right to organize self-help groups and cooperatives for purposes of obtaining equal access to economic opportunities through employment or self-employment" ${ }^{146}$. This represents a peculiar recognition of rural women's conditions and a similar right is not stated elsewhere for women in general.

Despite this, Cedaw lacks of mechanisms to enforce women's perspective and local customs (combined with masculin practices) continued to prevail and reinforced the patriarchal system. A more workable approach emerged in the 90s and the 1992 Convention on Biological Diversity recognized women's attitude towards practices relevant for the agricultural sector ${ }^{147}$. More precisely in its Preamble, par. 13, it is stated "the vital role that women play in the conservation and sustainable use of biological diversity" and it is also affirmed the need for the full participation of women at all levels of policy making concerning biological diversity conservation" ${ }^{148}$.

Such a vitality of women's involvement is particularly emphasized in Decision V/16 on art. 8 (j) of the Convention on Biological Diversity which underlined the need for greater attention to be put on indigenous women and their role in traditional knowledge of local communities ${ }^{149}$. Indeed, this Convention invited Parties to develop appropriate mechanisms for women's promotion and for their effective participation.

The women and environment approach of the Convention on Biological Diversity made room for a more gendered perspective at the Second Working

\footnotetext{
144 United Nations, Convention on the Elimination of All Forms of Discrimination Against Women, cit., art. 14, par. 1: "States Parties shall take into account the particula problems faced by rural women and the significant roles which rural women play in the economic survival of their fmilies, including their work in the non-monetized sectors of the economy [...]".

145 Ibidem, art. 14, par. 2, lett. a)- $h$ ).

146 Ibidem, art. 14, par. 2, lett. e).

147 United Nations, Convention on Biological Diversity, Rio de Janeiro 1992, 1760 UNTS 79.

${ }^{148}$ Helen Zweifel, "The Gendered Nature of Biodiversity Conservation", in NWSA Journal, vol. 9, issue 3,1997, p. 107-123.

${ }^{149}$ Convention on Biological Diversity, COP 5 Decision V/16, 15-26 May 2000, Nairobi Kenya, at <https://www.cbd.int/decision/cop/?id=7158>. [Retrieved on 30 September 2020].
} 
Group for the Review of Implementation of the Convention (July 2007) which adressed biodiversity strategies towards "gender considerations" 150 .

Some countries started to fulfil the mandate by forseeing gender strategies in their National Biodiversity Strategies and Action Plans: for example, Liberia's Plan suggested to consider how approaches towards biodiversity planning affect women and men differently and the potential impacts on their livelihoods. It also required to promote gender equality and the empowerment of women ${ }^{151}$.

However, feminization of agriculture has never been expressly named in international treaties and several challenges still remained, e.g. especially those concerning the managing of gender/biodiversity-related information and genderdisaggregated data: these latter ones are particularly relevant for agriculture since they help to understand different contribution of men and women to agriculture; the stereotypes that make women less visible than men for stakeholders; the biases for a lack of communication between women producers and male users of data.

Within the context of the Food and Agriculture Organization (FAO) the gender, environment and sustainable development approach in agriculture is particularly linked to the Farmers' rights, which are recognized by the Preamble and art. 9 of the International Treaty on Plant Genetic Resources for Food and Agriculture (following FAO Treaty).

The implementation of art. 9 of the FAO Treaty is grounded on the recognition of women's role in agriculture and, as emphasized by the consultations of Contracting Parties and organizations, special attention should be given to the inclusion of women farmers, "whose knowledge, capacities and key role as managers of biodiversity for food and nutrition security tends to be overlooked"152. Moreover, submissions by Contracting Parties revealed that little information were provided on the socio-economic and cultural diversity among

\footnotetext{
${ }^{150}$ See Quesada-Aguillar Andre, Mata Gabriela, Gender And National Biodiversity Strategies And Action Plans (NBSAPs), Convention on Biological Diversity-IUCN Fact Sheet at https://www.cbd.int/gender/doc/fs_uicn-cbd_nbsaps.pdf. [Retrieved on 27 September 2020].

${ }^{151}$ See CBD Strategy and Action Plan, Liberia' National Biodiversity Strategy and Action Plan, at https://www.cbd.int/doc/world//r/lr-nbsap-01-p1-en.pdf., p. 33-35. [Retrieved on 30 September, 2020].

152 Anja Christinck, "Farmers' Rights: Views, Experiences, Lessons Learned and Proposed National Measures for the Implementation of Article 9", Ad Hoc Technical Expert Group on Farmers' Rights Background Paper, Rome, 11-14 September 2018, p. 59.
} 
farmers and the role of women, as custodians of plant genetic resources, was "occasionally mentioned"153.

Gender sensitive agriculture and rural development policy and programmes ${ }^{154}$, in accordance with the Cedaw's proclamation of rural women's rights, are also in line with FAO's mandate to achieve food security by rising levels of nutrition and improving the lives of rural populations ${ }^{155}$.

In fact, the recognition of "the feminization of rural activities" in the $90 \mathrm{~s}^{156}$ and the lack of strategies to tackle specific needs of women were followed by the designing of a gender plan. In 2012, States adopted the Voluntary Guidelines on Responsible Governance of Tenure of Lands, Fisheries and Forests in the context of National Food Security under the auspices of the FAO Committee on World Food Security that reiterate principle of gender equality to ensure that women and girls have equitable tenure rights and access to land, fisheries and forest ${ }^{157}$. It was called upon States to ensure these rights regardless of women's civil and marital status and customary tenure systems, which exercise self-governance of land and forests, should promote, secure and provide equitable access for women ${ }^{158}$.

\footnotetext{
153 Ibidem, p. 72.

154 FAO, A Tool for Gender Sensitive-Agriculture and Rural Development Policy And Programme Formulation. Guidelines for Ministries of Agriculture and FAO, Rome, 2013, at < http://www.fao.org/3/i3153e/i3153e.pdf.> [Retrieved on 28 September, 2020]

${ }_{155}$ FAO, Fao Policy on Gender Equality. Attaining Food Security Goals in Agriculure and Rural Development, FAO, Rome, 2013, at < http://www.fao.org/3/a-i3205e.pdf >. [Retrieved on 28 September, 2020].

156 IICA, Women and Gender Equity in the New Vision of Rural Reality. A proposal from IICA for Strategic Action, Document Presented at the Eigh Regional Conference on Women in Latin America and the Xarrabbean, Lima Peru February 8-10, IICA-SIDA, San José, 2000.

157 Committee on World Food Security and FAO, Voluntary Guidelines on the Responsible Governance of Tenure of Land, Fisheries and Forests in The Context of National Food Security, Fao, Rome, 2012, at < http://www.fao.org/3/i2801e/i2801e.pdf > . [Retrieved on 28 September, 2020]. Also see Lorenza Paoloni, Antonio Onorati, "Regulation of Large-Scale Acquisitions of Land: The Case of the Voluntary Guidelines on the Responsible Governance of Land, Fisheries and Forests", in The Law and Development Review, vol. 7, issue 2, 2014, p. 369-400.

158 UNHR and UNWomen, Realizing Women's Rights to Land and Other Productive Resources, HR/PUB/13/04, United Nations, New York/Geneva, 2013 < https://www.ohchr.org/Documents/Publications/RealizingWomensRightstoLand.pdf > [Retrieved on 30 September, 2020].
} 
A peculiar attention for disaggregated data is present in FAO's struggle to elaborate gender statistics and manage agricultural information in a manner that take into account gender relations and skills in agriculture ${ }^{159}$.

In its monitoring activity, FAO has registered multiple experiences of feminization of agriculture using mainly two types of data to provide an overview of the phenomenon:1) the share of women economically active in agriculture and 2) time spent by women in agricultural activities. The main findings have shown that women comprise half or more of the agricultural labour force, especially in many African and Asian countries, and time spent by women in agriculture exceeds that of men since it includes many allied activities such as the preparing of food and collecting of fuel and water ${ }^{160}$.

To focus on the way feminization of agriculture is perceived, some rural settings in developing countries experienced such a phenomenon as a consequence of social changes urbanization, commercial farming growth or migration of young men: in these cases it brings women's poverty and work burden. On a different ground, it is more linked to economic issues in the Philippines where women used the remittances to hire labour and their difficulties are mainly present in accessing credit, inputs or services. This leads to consider that feminization of agriculture does not simply ask for the protection of vulnerable women in their working activities but it also requires support for women in their new role as temporary heads of household, as producers of food and decision-makers ${ }^{161}$.

The more recent step forward in the gender and environment discourse within the international forum and associated with feminization of agriculture could be retraced in the UN Declaration on the Rights of Peasants and Other People Working in Rural Areas that places the "feminization issue" in the context of

\footnotetext{
${ }^{159} \mathrm{FAO}$, Gender-Disaggregated Data for Agriculture and Rual Development, Socio-Economic and Gender Analysis Programme, Rome, 2003, at < http://www.fao.org/3/al210e/al210e00.pdf.>. [Retrieved on 28 September, 2020].

${ }^{160} \mathrm{FAO}$, The Role of Women in Agriculture, cit., p. 35.

161 FAO, Global Forum on Food Security and Nutrition, 17 July-6 August 2017, at < http://www.fao.org/3/a-i8222e.pdf>. [Retrieved on 28 Septemeber 2020] ; Alan De Brauw, Jikun Huang, Linxiu Zhang, Scott Rozelle, The Feminization of Agriculture with Chinese Characteristics, IFPRI Discussion $\quad 2012$ Paper, http://ebrary.ifpri.org/utils/getfile/collection/p15738coll2/id/126960/filename/127171.pdf>.

[Retrieved on 27 September, 2020].
} 
peasant and rural women's rights ${ }^{162}$. This Declaration takes into consideration the living experience of women as peasants and farmers and entitles them a number of key rights in a strong human rights approach ${ }^{163}$ to address specific abuses facing marginalized women.

It is in its Preamble that the UN Declaration on the Rights of Peasants and Other People Working in Rural Areas stresses that peasant women and other rural women play a significant role in contributing to the rural and national economy and in the survival of their families: in this sense the Declaration recognizes both their productive and reproductive work. It is also mentioned womens' involvement in the non-monetized sectors of the economy, their being excluded from ownership of land, equal access to land, financial resources and employment or social protection ${ }^{164}$. Such a recognition lies at the basis of those provisions that promote equality between men and women, their empowerment ${ }^{165}$ and equal access to health-care facilities, information and services $^{166}$.

Finally, the analysis of feminization of agriculture and the question of women's empowerment should be briefly deepened with regard to the "indigenous question" at international and national level. Indigenous women struggled together with men to define and promote the human rights paradigm, which was embodied by the Declaration on the Rights of Indigenous Peoples (art. 2) ${ }^{167}$, but the inextricable link between indigenous rights and women's rights they affirmed was not perceived and conventional applications and interpretation of human rights often distinguish sets of rights "sometimes even setting them in opposition to one another"168.

\footnotetext{
162 United Nations Declaration on the Rights of Paesants and Other People Working in Rural Areas, 17 December 2018, UN Doc. A/RES/73/165.

${ }^{163}$ Lorenza Paoloni and Simone Vezzani, "La Dichiarazione ONU sui diritti dei contadini e delle altre persone che lavrano nelle aree rurali: prime riflessioni", in Federalismi, issue 1, 2019, p. 133.

164 United Nations Declaration on the Rights of Paesants and Other People Working in Rural Areas, cit., Preamble, par. 13.

165 Ibidem, art. 2.

166 Ibidem, art, 2, lett. b); art.4.

167 UN Declaration on the Rights of Indigenous Peoples, 13 September 2007, UN Doc. A/RES/61/295, art. 2.

168 UN Office of the Special Adviser on Gender Issues and Advancement and the Secretariat of the United Nations Permanent Forum on Indigenous Issues, "Gender and Indigenous People's Human Rights,Briefing Note no. 6, February 2010, at
} 
Moreover in line with the objective of the ILO Convention, 1989 (No. 169) ${ }^{169}$, a crucial aspect concerns the promotion of equality and the closing of socioeconomic gaps based on the various dimensions of inequalities, i.e. inequalities experienced by indigenous women in comparison to non-indigenous women ${ }^{170}$. In fact, at the global level there is a substantial difference in the quality of work which is marked by poor working conditions, low pay and discrimination for indigenous women ${ }^{171}$. They are also more likely to be in the informal economy then their non-indigenous women counterpart ${ }^{172}$. Such an estimation also implies to closely look at the differences between Global South and North, with respect to the importance of women in agriculture. Women's labor contribution as agriculturalists is substantially different in the Global South and North and there are many issues to consider to compare women's agricultural productivity in the Global South and North, e.g. the impacts of climate change, land access, gender bias and the fact that women in the South are not generally included in large-cale, industrial farming ${ }^{173}$.

At national level, the recognition of rural women's knowlege, as key for a transition to gender food system, implies the acknowledgement of their effective participation in political decision-making processes by indigenous laws and traditional practices that have generally negatively affected women at the community level.

As a matter of fact, one of the main barrier to women's emancipation in agriculture is indigenous law that impede women, regardless of their maritial status, to inherit land. For example women cannot lease, rent, own land in the Ivory Coast and in most african traditions only men inherit land and father's

https://www.un.org/esa/socdev/unpfii/documents/BriefingNote6_GREY.pdf, p. 1. [Retrieved on 20 September 2020].

169 International Labours Organization, Convention (No. 169) Concerning Indigenous and Tribal Peoples in Independent Countries, 5 September 1991, 1650 UNTS 383, art. 2 , lett. c).

170 ILO, Implementing the ILO Indigenous and Tribal Peoples Convention No. 169. Towards an Inclusive, Sustainable and Just Future, 2019, at <https://www.ilo.org/wcmsp5/groups/public/--dgreports/---dcomm/---publ/documents/publication/wcms_735607.pdf,>, p. 38.[Retrieved on 29 September, 2020].

171 Ibidem, p.14.

172 Ibidem, p. 16.

${ }^{173}$ Tricia Glazebrook, Samantha Noll, Emmanuela Opoku, "Gender Matters: Climate Change, Gender Bias, and Women's Farming in the Global South and North" in Agriculture, MDPI, Open Access Journal, 2020, p. 2. 
possessions usually pass on to his brothers when only girls are in the family ${ }^{174}$. In Mozambique, women's equality and protection against discrimination on the basis of sex are guaranteed by constitutional principles but they have insecure rights to land and resources because indigenous laws and traditional practices favor men ${ }^{175}$.

Thus while women experience feminization of agriculture because they are primary producers of food for their families, they still continue to depend on men for access to land and means of production. Despite the fact that India and nearly every African country have ratified the Cedaw and passed laws on rights of female farmers, many obstacles for farmer women are deep-rooted cultures of masculinity and patriarchy ${ }^{176}$.

\section{Conclusion}

Ecofeminism entered the international environmental law scenario by bringing an environmental sexism to cast light on the intimate relationship between nature and women but the advent of socio-economic changes, degradation of environment and ecological risks, which negatively affected women more than men, gave birth to new feminist approaches (i.e. women and environment gender, environment and sustainable development) whose aim was to bring out women's condition, to promote their representation and face gender inequalities in contemporary society.

Grounded on the analysis of these various theories, their discrepancies and critiques, this paper firstly examines the entering of the feminist and gender approaches into the international environmental law system to then seek to verify whether treaties and soft law have used their reasoning to tackle the feminization of agriculture phenomenon.

\footnotetext{
174 Pauline Yao, The Right to inherit in Customary Law: An Obstacle to Women's Emancipation in Ivory Coast, 2014, at <http://www.citego.org/bdf_fiche-document-1388_en.html.>. [Retrieved on 29 September, 2020].

${ }^{175}$ Anna Knox, "Christopher Tanner, Securing Women's Land Rights in Mozambique", in Focus on Land in Africa, 2011.

${ }^{176}$ Vani Swarupa Murali, "In India and Africa, Women Farmers Lack Land Rights", in The Interpreter, 2012, at <https://www.lowyinstitute.org/the-interpreter/india-and-africa-womenfarmers-need-land-rights>. [Retrieved on 29 September, 2020].
} 
The study shows that feminization of agriculture itself could be seen as a stimulus and a challenge for feminist perspectives: it introduces a "new battle" to make women visible in the crucial sector of agriculture and promote equal means of production for both men and women. Indeed, women have been traditionally associated with a sphere of reproduction consisting of women's unpaid domestic and community work for subsistence ${ }^{177}$. The focus on agriculture is crucial because limited results to advance gender equality in this key sector could possibly overwhelm progress made by women's, especially in the field of human rights. Feminism and gender movements cannot champion women's rights without advancement in the reallocation of resources under a gender paradigm in agriculture and the protection of women appears to be a hollow and unrealistic aspiration if it does not consider the conditions of peasants and rural women.

The perspectives described let this research discover women fighting for their independence and for being considered as co-main characters in society; furthermore movements based on feminist and gender theoretical approaches show their struggle to redirect environmental strategies towards fairer sustainable policies and practices. This awareness spread in many rural settings and women working on the land and allied sectors rose up to oppose their very limited recognition in local and community contexts, to overcome the patriarchal systems they live in and fight against the sole assigned roles as "carers in need". In fact, both feminist environmental movements and female farmers' claims were concerned with gender-blindness of mainstream development ${ }^{178}$.

As a matter of fact, it is surely tempting to see gender obstacles and inequalities being smoothed by the proclamations of treaties and soft law instruments and to consider this advancement as the award of decades of feminist struggles but such a consideration is risky and disproved by reality at present since, at a closer look, official moments of rights' recognition have rarely implied a positive change in women's empowerment and managerial feminiziation in the context

\footnotetext{
177 Jenny Cameron, J.K. Gibson-Graham, "Feminising the Economy: Metaphors, Strategies, Politics", in Gender, Place \& Culture. A Journal of Feminist Geography, 2003, p. 145-157.

178 Lata Narayanaswamy, "Whose Feminism Counts? Gender(ed) Knowledge and Professionalisation in Development", in Third World Quarterly, vol. 37, issue 12, 2016, p. 21562175.
} 
of feminization of agriculture. This because of the lack of a proper look at gender relations, unequal social construction of gender and unfair distribution of roles, responsibilities and expectations for both men and women.

Removing barriers for women firstly implies to ensure equal access to resources, prevent various forms of discrimination and allow women to fail or to succeed just exactly like men fail or succeed. In the rural setting, this means giving voice to female farmers and paesants who demand to be entitled to rights to lands, to improve their ability to have credit and commit to design gender strategies which take into account women as managers of agricultural workforce.

Within the legal systems, realistic steps forward should be based upon lifelike understanding of women's experiences which consider both gender roles in society and the difference between the household and public sphere. In fact, not only a change in male-female stereotypes within society is crucial, but also a redistribution of tasks in private life is needed. This would mean guaranteeing women in agriculture a remunerated contribution for their being part of food production and relieve them from the burden of their sole responsibilities as family carers.

The analysis of the role played by feminist and gender theories has shown that the permanent drive of feminist doctrines and movements was crucial in underpinning the validity of programmes putting attention on women and the feminist approaches have heavily worked to critize the justification of women's exclusion from and impact on global politics ${ }^{179}$.

These efforts led to certain kind of progresses for the incorporation of the gender perspective even in the international environmental law field and created a linkage between environemental issues and agriculture. Moreover, environmental treaties are now going beyond the initial tendency to put together all environmental problems into the same undifferenciated "woman category" trying to focus on minor and localized peculiarities of rural and paesant women and short-terms objectives.

\footnotetext{
${ }^{179}$ As said by Cynthia Enloe: "Virtually everyone at the top of foreign-policy bureaucracies is male", see Cynthia Enloe, Banans,Beaches and Bases: Making Feminist Sense of International Politics, University of California Press, Berkeley/Los Angeles/London, 1990, at p. 5.
} 
But, despite this, the construction of "feminization" at the international level has still attained a negative significance as proved by the social-economic events with which this word was associated, such as "feminization of poverty" 180 in the Agenda 21 or the term "feminization" in the agricultural sector where it simply indicates the labor aspect of feminization without sensing women's empowerment.

The same negative aspects have been noted by researchers in India, who specified how "the feminization of agriculture may better be described as the feminization of agrarian distress" 181 and in some contexts feminization of agriculture and its negative consequences have been associatied with a doubling of suicide among female farmers in the recent years ${ }^{182}$.

Moreover, the framing of feminization of agriculture is almost exclusively polarized towards the male-female distinctions without engaging with the more highly politicized issues of differences among women grounded on social classes and ethnicity.

As an example of that, researches have demonstrated that female labour shares tend to be higher where women are more educated ${ }^{183}$ and as reported by CGIAR even if gender gap in landholding has progressively diminished, in Ghana a "new gender gap" has been ascertained: "Women in matrilineal ethnic groups are more likely to hold land, but hold plots of smaller size than women in patrilineal ethnic groups"184. This shows that women's access to land may be

180 Diane Pearce, "The Feminization of Poverty: Women, Work, and Welfare", in Urban and Social Change Review, vol. 11, p. 28-36; Sylvia Chant, "Re-Thinking the Feminization of Poverty in Relation to Agregate Gender Indices", in Journal of Human Development, vol. 7 issue 2, 2006, p. 201-220.

181 Itishree Pattnaik, Kuntala Lahiri-Dutt, Stewart Lockie, Bill Pritchard, "The Feminization of Agriculture or the Feminization of Agrarian Distress? Tracking the Trajectory of Women in Agricuture in India", Journal of Asia Pacific Economy, 2018, p. 138-155.

182 Ambika Pandit, Women from 'Farm Suicide Families' Demand Special Rehab Package, Uniform Compensation Policy, in The Times of India, January, 28, 2020, at $<$ https://timesofindia.indiatimes.com/india/women-from-farm-suicide-families-demand-specialrehab-package-uniform-compensation-policy/articleshow/73686539.cms.> [Retrieved on 28 September 2020].

${ }^{183}$ Amparo Palacios-Lopez, Luc Christiaensen, Talip Kilic, "How much of the Labor in African Agriculture is Provided by Women?", in Food Policy, 2017, p. 52-63.

${ }_{184}$ See Monica Schuster, Isabel Lambrecht, Gender Roles in Agriculture: Did Anything Change?, 2017, at <https://a4nh.cgiar.org/2017/10/25/gender-roles-in-agriculture-did-anythingchange/>. [Retrieved on 27 September, 2020] Also see Isabel Lambrecht, Monica Schuster, Sarah Asare, Laura Pelleriaux, "Changing Gender Roles in Agriculture?. Evidence from 20 Years of Dtat in Ghana", IFPRI Discussion Paper, march 2017, at < 
not as limited as advocacy tend to claim but it still depends on gender inequalities implying ethnic connotations and local customs.

So, the question is not whether feminization exists or not but how it operates and how it can be conceptualized through feminist point of view which takes into account gender processes, the multiplicity of women's conditions and the empowerment process. International environmental law could help this process by linking the crucial role of women in sustainable development and the way they operate in agriculture.

The United Nations System undoubtedly marked environment and agriculture as arenas for women by taking into account the claims of feminist movements of the 70 s and giving attention to the voices of gender analysis ${ }^{185}$. But, several steps forward should be done. The postmodern critiques of feminism keep pushing new strategies and paradigms to frame feminization of agriculture, routing it through the social construction of gender and environmental justice ${ }^{186}$.

To conclude, the promotion of a feminist-gender vein as a transformative process in international law ${ }^{187}$ brought the construction of alliances and transversalism ${ }^{188}$ in the field of environmental law (especially in the field of climate change and environmental justice) and has the potentiality to frame the feminization of agriculture phenomenon in the future by focusing of its managerial aspect to achieve relevant goals, such as women's empowerment and sustainable development. In broad terms, to understand the tendencies of women's work in agriculture, it is useful to locate some aspects and claims of the above mentioned approaches in environmental law into the context of agricolture.

http://ebrary.ifpri.org/utils/getfile/collection/p15738coll2/id/131105/filename/131316. pdf>. [Retrieved on 27 September, 2020].

${ }_{185}$ Christine Okali, Searching for New Pathways Towards Achieving Gender Equity. Beyond Boserup and 'Women's Role in Economic Development', in Esa Working Paper No. 11-09, March 2011, <http://www.fao.org/3/a-am314e.pdf. >. [Retrieved on 30 September, 2020].

${ }^{186}$ Rebecca Elmhirst, "Introducing New Feminist Political Ecologies", in Geoforum, 2011, vol. 42, issue 2, p. 129-132; Kaitlyn Spangler and Maria Elisa Christle, "Renegotiating Gender Roles and Cultivation Practices in the Nepali Mid- Hills: Unpacking the Feminization of Agriculure", cit., at p. 418.

187 Rosa Ehrenreich Brooks, "Feminism and International Law: An Opportunity fro Transformation", in Yale Journal of Law and Feminism, vol. 14, 2002, p. 345-361; Rachel Saloom, "A Feminist Inquiry into International Law and International Relations", in Roger Williams University Law Review, vol.12, issue 1, 2006, p. 159-181.

188 Andreas Philippopoulos and Mihalopoulos Victoria Brooks, (eds.), Research Methods in Environmental Law: A Handbook, Edward Elgar, Cheltehnam/Northamptoon, 2017. 
In the field of feminization of agriculture, feminist and gender approaches would foster emancipation of women from subjection to men and claim for rights and freedom in market relationships, this would allow them to become entrepreneurs and to rescue women from peasantization or androcentric schemes. In this sense feminist and gender perspectives could guide international environmental law to an "ethic of rights" and abandon the "ethic of care" that has been traditionally spread and passed down as moral basis to dominate and control women ${ }^{189}$.

\section{References}

Alesina, Alberto; Giuliano, Paola; Nunn, Nathan, "On the Origin of Gender Roles: Women and the Plough", in Quarterly Journal of Economics, 2013, vol.128, issue 2, p. 469-530

Archambault, Anne, A Critique of Ecofeminsm, Canadian Woman Studies/Les cahiers de la femme, vol. 13, issue 3, 1993, p. 19-22

Agarwal, Bina, "The Gender and Environmetal Debate: Lessons from India", in Feminist Studies, vol.18, issue 1, 1992, p. 119-158

Alston, Margaret, Breaking Through the Grass Ceiling. Women, Power and Leadership in Agricultural Organisations, Harwood Academic Publishers, Amsterdam, 2000

Baker, Susan, "The Principles and Practice of Ecofeminism: A Review", in Journal of Gender Studies, vol. 2, issue 1, 1993, p. 4-26.

Bem, Sandra L., The Lenses of Gender: Trasforming the Debate on Sexual Inequality, New Haven, Yale UNiversity Press, 1993

Benería, Lourdes, Berik Günseli and Floro, Maria S., Gender, Development, and Globalization. Economics as if all People Mattered, Routledge, New York/London, 2003.

Bieri, Sabin, "New Ruralities - Old Gender Dynamics? A Reflection on Highvalue Crop Agriculture in the Light of the Feminizaztion Debates", in Geographica Helvetica, vol. 69, 2014, p. 281-290,

Biever, Joan L.; De Las, Fuentes; Cynthia, Cashion, Lisa; Franklin, Cynthia, "The Social Construction of Gender: A Comparison of Feminist and Postmodern Approaches", in Counselling Psychology Quarterly, vol. 11, issue 2, 1998, p. 163-179

189 Linda A. Malone, "Environmental Justice Reimagined Through Human Security and PostModern Ecological Feminism: A Neglected Perspective on Climate Change", in Fordham International Law Journal, vol. 38, issue 5, 2015, p. 1445-1471, at 1454. 
Birke, Lynda I.A. and Vines, Gail, "Beyond Nature Versus Nurture: Process and Biology in the Development of Gender", in Women's Studies International Forum, vol 10, issue 6, 1987, p. 555-570

Bock, Bettina B.; Shortall, Sally, (eds.), Rural Gender Relations: Issues and Case Studies, Cabi Publishing, Cambridge, 2006

Bohan, Janis S., "Essentialism, Constructionism, and Feminist Psychology", in Psychology of Women Quarterly, vol. 17, issue 1, 1993, p. 5-21

Boserup, Esther, Woman's Role in Economic Development, Earthscan, London/New York. 1970

Braidotti, Rosi; Charkiewicz, Ewa; Häusler, Sabine; Wieringa, Saskia, Women, the Environement and Sustainable Development. Towards a Theoretical Synthesis, ZED BOOKS in association with INSTRAW, London/New Jersey/Santo Domingo, 2004

Brandth, Berith, "Changing Femininity The Social Construction of Women Farmers in Norway", in Sociologia Ruralis. Journal of the European Society for Rural Sociology, vol. 34, issues 2-3, 1994, p.127-149

Brandth, Berith, "On the Relationship Between Feminism and Farm Women", in Agriculture and Human Values, 2002, vol.19, issue 2, p.107-117

Brooks, Ehrenreich Rosa, "Feminism and International Law: An Opportunity for Transformation", in Yale Journal of Law and Feminism, vol. 14, 2002, p. 345361

Buckingham, Susan, "Ecofeminism in the Twenty-First Century", in The Geographical Journal, vol. 170, issue 2, 2004, p. 146-154

Cameron, Jenny; Gibson-Graham J.K., "Feminising the Economy: Metaphors, Strategies, Politics", in Gender, Place \& Culture. A Journal of Feminist Geography, 2003, p. 145-157

Carlassare, Elizabeth, "Essentialism in Ecofeminist Discourse", in Carolyn Merchant (ed.), Ecology, Humanities Press, New York, 1994, p. 220-234

Carson, Rachel, Silent Spring, Mariner Books, Boston/New York, 2002

Chant, Sylvia, "Re-Thinking the Feminization of Poverty in Relation to Agrregate Gender Indices", in Journal of Human Development, vol. 7, issue 2, 2006, p. 201-220

Charlesworth, Hilary, "Women as Sherpas: Are Global Summits Useful for Women?", in Feminist Studies, vol. 22, issue 3, 1996, p. 537-547

Charlesworth, Hilary, "Feminist Methods in International Law", in The American Journal of International Law, vol. 93, 1999, p. 379-394

Charlesworth, Hilary; Chinkin, Christine; Wright, Shelley, "Feminist Aproaches to International Law", in The American Journal of International Law, vol. 85, issue 4,1991 , p. 613-645

Christinck, Anja, "Farmers' Rights: Views, Experiences, Lessons Learned and Proposed National Measures for the Implementation of Article 9", Ad Hoc Technical Expert Group on Farmers' Rights Background Paper, Rome, 11-14 September 2018 
Conley, Verena Andermatt, Ecopolitics. The Environment in Poststructuralist Thought, Routledge, London/New York, 1997

Corazza, Chiara, "Il principio femminile/materno. La critica allo sviluppo di J.C. Kumarappa e V. Shiva", in Annalisa Zabonati (ed.), Ecofemminismo/Ecofeminsm, in Deportate, esuli, profughe. Rivista telematica di studi sulla memoria femminile, issue 20, 2012, p. 90-104

D’Eaubonne, Françoise, Le féminisme ou la mort, P. Horay, Paris, 1974

Dankelman, Irene; Davidson, Joan, Women and Environment in the ThirdWorld: Alliance for the Future, Earthscan Publications, London, 2004, Foreword, p. IX

Dankelman, Irene, "Women Advocationg for Sustainable Livelihoods and Gender Equality on the Global Stage", in Wendy Harcourt (ed.), Women Reclaiming Sustainable Livelihoods: Spaces Lost, Spaces Gained, Palgrave MacMillan, New York, 2012, p. 21-41

De Brauw, Alan; Li, Qiang; Chengfang, Liu; Rozelle, Scott; Zhang, Linxiu, "Feminization of Agriculture in China? Myths Surrounding Women's Participating in Farming", in The China Quarterly, No. 194, 2008, p. 327-348

De Schutter, Oliver, "The Agrarian Transition and the 'Feminization of Agriculture'", in Food and Sovereignty: A Critical Dialogue, Conference Paper of the International Conference Yale University, September 14-15, 2013, issue 37, p. 1-43

De Schutter, Oliver, "The Emerging Human Right to Land", in Internationa ICommunity Law Review, vol. 12, issue 3, 2010, p. 303-334

Dolan, Cathrine; Sorby, Kristina, "Gender and Employment in High-Value Agriculture Industries", in Agriculture and Rural Development Working Paper 7, Washington DC, World Bank. 2003

Douglas, A. Vakoch; Mickey, Sam (eds.), Ecofeminism in Dialogue, Lexington Books, Lanham/Boulder/New York/London, 2018

Elmhirst, Rebecca, "Introducing New Feminist Political Ecologies", in Geoforum, vol. 42, issue 2, 2011, p. 129-132

Enloe, Cynthia H., Does Khaki Become You? The Militarisation of Women's Lives, Pluto Press, London, 1983

Enloe, Cynthia H., Banans,Beaches and Bases: Making Feminist Sense of International Politics, University of California Press, Berkeley/Los Angeles/London, 1990

Escobar-Lemmon, Maria C.; Taylor-Robinson, Michelle M. (eds.), Representation: The Case of Women, Oxford University Press, New York, 2014.

Fiaccadori, Elisa, "The Question of 'Nature': What has Social Constructionism to Offer Feminist Theory?", in Sociology Working Papers, 2006, p. 1-17

Focarelli, Carlo, Costruttivismo giuridico e giurisdizioni internazionali, Kluwer/Cedam, 2019, Milano

Fuss, Diana, Essentially Speaking: Feminism, Nature \& Difference, Routledge, New York/London, 1989 
Gaard, Greta, "Ecofeminism Revisited: Rejecting Essentialism and Re-Placing Species in a Material Feminist Environmentalism", in Feminist Formations, vol. 23, issue 2, 2011, p. 26-53

Garrity-Bond, Cynthia, "Ecofeminist Epistemology in Vandana Shiva's the Feminin; The Principle of Prakriti and Ivone Gebara's Trinitaria Cosmology", in Feminist Theology, vol. 26, issue 2, 2018, p. 185-194

Gartaula, Hom Nath; Niehof, Anke; Visser, Leontine, "Feminisation of Agriculture as an Effect of Male Out-migration: Unexpected Outcomes from Jhapa District, Eastern Nepal", in The International Journal of Interdisciplinary Social Sciences, vol. 5, 2010, p. 565-577

Glazebrook, Tricia; Noll, Samantha; Emmanuela, Opoku, "Gender Matters: Climate Change, Gender Bias, and Women's Farming in the Global South and North" in Agriculture, MDPI,Open Access Journal, 2020, vol. 10, p. 1-25.

Gornick, Vivian; Moran, Barbara K. (eds), Woman in sexist society: Studies in Power and Powerlessness, Basic Books, New York, 1971

Harcourt, Wendy, "Negotiating Position in the Sustainable Development Debate: Situating the Feminist Perspective", in Wendy Harcourt (ed), Feminist Perspectives on Sustainable Development, Zed Books LTD, London/New Jersey, 1994, p. 22

Harding, Sandra, The Science Question in Feminism, Cornell University Press, New York, 1986

Hausler, Sabine, "Gender and the Environment: Recent Initiatives to Improve Sustainable Development Policy, Planning and Practice", in Gender, Technology and Development, 1997, n. 3, p. 327-348

Henry, Astrid, Not My Mothers' Sister. Generational Conflict And The Third -Wave Feminsm, Indiana University Press, Boolongton And Indianapolis, 2004

IICA, Women and Gender Equity in the New Vision of Rural Reality. A proposal from IICA for Strategic Action, Document Presented at the Eigh Regional Conference on Women in Latin America and the Xarrabbean, Lima Peru February 8-10, IICA-SIDA, San José, 2000

International Labours Organization, Convention (No. 169) Concerning Indigenous and Tribal Peoples in Independent Countries, 5 September 1991, 1650 UNTS 383.

Jackson, Cecile "Women/Nature or Gender/History? A Critique of Ecofeminist 'Development', in The Journal of Paesant Studies, vol. 20, issue 3, 1993, p. 389-418

Jackson, Cecile, "Doing What Comes Naturally? Women And Environment In Development", In World Development, 1993, p.1949

Jackson, Cecile; Ruth, Pearson (ed.), Feminist Visions Of Development: Gender Analysis And Policy, Routledge, London/New York, 1998

Jellison, Katherine, Entitled To Power: Farm Women And Technology, 19131963, The University of North Carolina Press, 1993 
Jenkins, Willis; Bauman, Whitney (eds.), The Spirit of Sustainability, Berkshire Publishing Group, Massachussetts, 2010

Jia-Cheng, Liu, Zhi-Gang, Xu, Qiu-Fen, Zheng and Hua, Lillian, "Is The Feminization Of Labour Harmful To Agricultural Production? The DecisionMaking And Production Control Perspective", in Journal of Integrative Agriculture, vol. 18, issue 6, 2019, p. 1392-1401

Jiggins, Janice, "The Feminization Of Agriculture", in The Brown Journal Of World Affairs, vol.5, issue 2, 1998, p. 251-262

Jiménez Guzmán, Alexsa, "Conocimientos tradicionales de mujeres mapuches en la agricultura tradicional, territorio Naqche de La Araucanía, Chile", in Cecilia Mayorga Muñoz, Ferdinando Treggiari (eds.) Biodiversidad y conocimientos tradicionales. Perspectivas históricas, socioculturales y jurídicas, Universidad de La Frontera-Università degli Studi di Perugia, Temuco- Perugia, 2018 p. 97110.

Joyner, Christopher C. and Little, George E., "It's Not Nice To Fool Mother Nature! The Mystique of Feminist Approaches to International Environemental Law", in Boston University International Law Journal, 1996, p. 223-266

Kassie, Menale; Stage, Jesper; Teklewold, Hailemariam; Erenstein, Olaf, "Gendered Food Security In Rural Malawi: Why Is Women's Food Security Status Lower?", In Food Security, vol.7, issue 6, 2015, p.1299-1320

Kheel, Marti, Nature Ethics: An Ecofeminist Perspective, Rowman \& Littlefield Publishers, Lanham/Boulder/New York/Toronto/ Plymouth, 2008, p. 8

Knox, Anna; Christopher, Tanner, "Securing Women's Land Rights In Mozambique", in Focus On Land In Africa, 2011

Koczberski, Gina, "Women in Development: A Critical Analysis", in Third World Quarterly, 1998, vol 19, issue 3, p. 395-410

Larrére, Catherine, "La Nature A-T-Elle Un Genre? Variétés D'écoféminisme", in Cahiers Du Genre, n. 59, 2015, p. 103-125

Lastarria-Cornhiel, Susana, Feminization of Agriculture: Trends and Driving Forces, Background Paper For the World Development Report 2008, RimispLatin American Center for Rural Development - International Development Research Centre, Ottawa, 2006

Leach, Melissa; Green, Cathy, "Gender and Environmental History and Nature to Gender Analysis of Ecology and Politics", in Environment and History, issue 3, 1997, p. 343-370

Lorber, Judith; Farrell, Susan A., The Social Construction Of Gender, Sage Publications, Newbury Park, 1991.

Malone Linda A., "Environmental Justice Reimagined Through Human Security and Post- Modern Ecological Feminism: A Neglected Perspective on Climate Change", in Fordham International Law Journal, 2015, vol, 2, p. 1445-1471

Meinzen, Ruth - Dick; Quisumbing, Agnes; Biermayr-Jenzano, Julia; Wilde, Vicki; Noordeloos, Marco; Rgasa, Catherine; Beintema, Nienke, "Engendering Agricultural Research, Development, and Extension", in Ifpri Reseach Monograph, Washington, 2011, p. 11 
Mellor, Mary, Feminism and Ecology, New York University Press, New York, 1997

Mellor, Mary, Women, "Nature And The Social Construction Of 'Economic Men'”, In Ecological Economics, vol. 20, issue 2, 1997, p. 129-140

Mies, Maria, Patriarchy And Accumulation On A World Scale, London, Zed Books, 1986, p. 16-17

Moore, Niamh, "Ecofeminism and Third Wave Feminism? Essentialism, Activism and the Academy", in Stacy Gillis, Gillian Howie and Rebecca Munford (eds.), Third Wave Feminism. A Critical Exploration, Palgrave MacMillan, New York, p. 227-239

Morrow, Karen, "Gender and the Sustainable Development Goals", in Duncan French and Louis J. Kotzé (eds.), Sustainable Development Goals, Edward Elgar Publishing, Cheltenham, 2018, p. 149-172

Mukoni, Manuku, "Gender Identity Construction, Community Environmental Education and Ecofeminism: Untapped Interconnections", In International Journal of Research and Innovation in Social Science, Vol. 3, issue 7, 2019, p. 309-317

Narayanaswamy, Lata, "Whose Feminism Counts? Gender(Ed)Knowledge Ans Professionalisation In Development", in Third World Quarterly, vol. 37, issue 12, 2016, p. 2156-2175

Nhanenge, Jytte (ed.), Ecofeminsm. Towards Integrating The Concerns Of Women, Poor People, and Nature Into Development, University Press of America, Maryland, 2011

Nightingale, Andrea J., "The Nature of Gender: Work, Gender, and Environment", in Environment and Planning D: Society and Space, vol. 24, issue 2, 2006, p. 165-185

Norgaard Kari Marie, "The Essentialism of Ecofeminism and the Real", in Organization \& Environment, vol. 11 issue 4, 1998, p. 492-497

Osmond, Marie Withers; Thorne, Barrie, "Feminist Theories. The Social Construction of Gender in Families and Society", in Pauline Boss, William J. Doherty, Ralph La Rossa, Walter R. Schumm, Suzanne K. Steinmetz (Eds.), Sourcebook of Family Theories and Methods. A Contextual Approach, Springer Boston, 1993, p. 591-625

Palacios-Lopez, Amparo; Christiaensen, Luc; Kilic, Talip, "How Much of the Labor in African Agriculture is Provided by Women?", in Food Policy, 2017, p. $52-63$

Paltasingh, Tattwamasi; Lakshmi, Lingam, "Production and Reproduction in Feminism: Ideas, Perspectives and Concepts", in IIM Kozhikode Society \& Management Review, vol. 3, issue 1, 2014, p. 45-53

Paoloni, Lorenza; Onorati, Antonio, "Regulation of Large-Scale Acquisitions of Land: The Case of the Voluntary Guidelines on the Responsible Governance of Land, Fisheries and Forests", in The Law and Development Review, vol. 7, issue 2,2014 , p. $369-400$ 
Paoloni, Lorenza; Vezzani, Simone, "La Dichiarazione ONU sui diritti dei contadini e delle altre persone che lavrano nelle aree rurali: prime riflessioni", in Federalismi, 2019, issue 1, p. 1-33

Pattnaik, Itishree; Lahiri-Dutt, Kuntala; Lockie, Stewart; Pritchard, Bill, "The Feminization of Agriculture or the Feminization of Agrarian Distress? Tracking the Trajectory of Women In Agricuture in India", in Journal Of Asia Pacific Economy, 2018, p. 138-155

Pearce, Diane, "The Feminization of Poverty: Women, Work, And Welfare", in Urban And Social Change Review, 1978, vol. 11, p. 28-36

Pease, Bob, "Recreating Men's Relationship with Nature: Toward a Profeminst Environmetalism", in Men And Masculinities, Vol. 22, issue 1, 2019, p. 113-123

Perkins, Patricia E., "Feminist Ecological Economics and Sustainability", in Journal Of Bioeconomics, 2007, p. 227-244

Philippopoulos, Andreas, Mihalopoulos Victoria Brooks, (eds.), Research Methods in Environmental Law: a Handbook, Edward Elgar, Cheltehnam/Northamptoon, 2017

Pini, Barbara; Brandth, Berit; Little, Jo, (Eds) Feminisms and Ruralities, Lexinton Books, Lanham/Boulder/ New York/ London, 2015

Plumwood, Val, "Nature, Self, and Gender: Feminsm, Environmental Philosophy, and the Critique of Rationalism", in Hypatia, vol. 6, issue 1, 1991, p. 3-27

Plumwood, Val, Feminism and the Mastery of Nature, London, Routledge, 1993

Pradeep, Joliya; Amita, Maurya; Shilpi, Sisodia; Virendra, Kamalvanshi, Feminization of Agriculture: A Dream Project, in Indian Journal of Economics and Development, vol. 13, issue 1, 2017, p. 769 ss.

Puleo, Alicia H., What Is Ecofeminism, in Quaderns De La Mediterrania, 2017, vol. 25, p. 27-34

Quisumbing, Agnes R.; Meinzen - Dick, Ruth; Raney, Terri L., Croppenstedt André, Behrman, Julia A. and Peterman, Amber (eds.), Gender in Agriculture. Closing the Knowledge Gap, FAO-Springer, New York/London, 2014

Resurrección, Bernadette P., "Persistent Women And Environementa Linkages In Climate Change And Sustainable Development Agendas", in Women's Stidies International Forum, 2013, p. 33-43

Resurrección, Bernadette P., "Gender and Environment from 'Women, Environment and Development' to Feminist Political Ecology, in Mac Gregory Sherilyn (ed.), Routledge Handbook of Gender and Environment, Routledge, Oxon, 2017, p. 71-85

Rowe, Audrey, "The Feminization Of Poverty: An Issue For The 90's", in Yale Journal of Law and Feminism, vol. 4, issue 1, 1991, p. 73-79.

Saloom, Rachel, "A Feminist Inquiry into International Law and International Relations", in Roger Williams University Law Review, vol.12, issue 1, 2006, p. 159-181 
Shiva, Vandana, Staying Alive: Women, Ecology And Development, Zed Books, London, 1989

Shiva, Vandana, Biopiracy: The Plunder of Nature and Knowledge, South and Press, Boston, 1997

Shiva, Vandana; Mies, Maria, Ecofeminism, Zed Books, London, 2014

Simon, Anne E., "Whose Move? Breaking The Stalemate In Feminist And Environmental Activism", in Ucla Women's Law Journal, 1992, p. 145-164

Skeggs, Beverly, Formations of Class \& Gender. Becoming Respectable, SAGE Publications, London, 1997

Song, Yiching, "New" Seed In "Old" China: Impact Of The Cimmyt Collaborative Pragramme On Maize Breeding In South -Western China, Phd Thesis, Wagening Agricultural University, Wageningen, 1998

Spangler, Kaitlyn; Christle, Maria Elisa, "Renegotiating Gender Roles And Cultivation Practices In The Nepali Mid- Hills: Unpacking The Feminization Of Agriculure", in Agriculture And Human Values, vol. 37, 2020, p. 415-432

Spretnak, Charlene, "Ecofeminism: Our Roots and Flowering", in Irene Diamond and Gloria Feman Orenstein (eds.), Reweaving the World: The Emergence of Feminism, Sierra Club Books,San Francisco, 1990, p. 3-14

Stanley, Liz, "Should 'Sex' Really Be 'Gender' - or 'Gender' Really Be 'Sex'”, in Stevi Jackson and Sue Scott (eds.) Gender: A Sociological Reader, Routledge, London/New York, 2002, p. 31-41

Steans, Jill, Gender and International Relations. Theory, Practice, Policy, Polity Press, Cambridge, 2013

Sturgeon, Noël, Ecofeminist Nature: Race, Gender, Feminist Theory And Political Action, Routledge Taylor \&Franscis Londonand New York, 1997. p. 10

Sturgeon, Noël, "Ecofeminist Natures And Transnational Environemental Politics", in Heather Eaton, Lois Ann Lorentzen (Eds.) Ecofeminsm and Globalization: Exploring Culture, Context, and Religion, Rowman \&Littlefield Publishers, New York/Toronto/Oxford, 2003, p. 91-122.

Sweetman, Caroline (ed.), Women, Land and Agriculture, Oxfam Publishing, Oxford, 1999

Tickner, Ann J., Gender in International Relations: Feminist Perspectives on Achieving Global Security, Columbia University Press, New York, 1992

Tzeporah, Berman, "The Raper Of Mother Nature? Women In The Language Of Environmental Discourse", in Trumpeter, vol. 11, no. 14, 1994, p. 173-178

United Nations, The United Nations Conference on the Human Environment, June 1972, UN Doc. A/CONF.48/14/Rev. 1

United Nations, Convention on the Elimination of All Forms of Discrimination Against Women, 18 December 1979, 1249 UNTS 13

United Nations, Report of the World Conference to Review and Appraise the Achievements of the United Nations Decade for Women: Equality, Developmnet and Peace, Nairobi 15-26 July 1985, UN Doc. A/CONF.116/28/Rev. 1 
United Nations, Report of the Fourth World Conference on Women, Beijing , 415 September 1995, UN Doc. A/CONF.177/20/Rev. 1

United Nations, Report of the World Summit on Sustainable Development, Johannesburg, South Africa, 26 August- 4 September 2002, UN Doc. A/CONF.199/20

United Nations, Plan of Implementation of the World Summit on Sustainable Developmment, 4 September 2002, UN Doc. A/CONF.199/20

United Nations, Transforming Our World: The 2030 Agenda for Sustainable Development, 21 October 2015, UN Doc. A/RES/70/1

United Nations, Convention on Biological Diversity, Rio de Janeiro 1992, 1760 UNTS 79

Vanegas, Marta R.; Pruitt, Lisa R., "Cedaw And Rural Development: Empowering Women with Law from the Top Down, Activism from the Bottom Up", in University of Baltimore Law Review, vol. 41, issue 2, p. 263-320, 2012.

Verchick Robert R.M., "In A Greener Voice: Feminist Theory And Environemental Justice", in Harvard Women's Law Journal, 1996, vol. 19, p. 2388

Vidhu, Verma, "Endengering Development: Limits Of Feminist Theories And Justice", in Economic And Political Weekly, p. 5246-5252, 2004

Wagle, Radha; Pillay, Soma; Wright, Wendy, Feminist Institutionalism And Gendered Bureaucracies: Forestry Governance In Nepal, Palgrave Macmillan, Singapore, 2020

Waring, Marylin, If Women Counted: A New Feminist Economics, Harper \& Row, New York, 1988

Warren, Karen, "The Power And The Promise Of Ecological Feminism", in Environmental Ethics, vol. 12, issue 2, 1990, p. 125-146

Zweifel, Helen "The Gendered Nature of Biodiversity Conservation", in Nwsa Journal, vol. 9 issue 3, 1997, p. 107-123

\section{Web References}

Cambridge Dictionary, v. Feminization, < https://dictionary.cambridge.org/dictionary/english/feminization.> Cambridge University Press 2020. [Retrived on 27 September, 2020]

CBD Strategy and Action Plan, Liberia' National Biodiversity Strategy and Action Plan, at https://www.cbd.int/doc/world//r/lr-nbsap-01-p1-en.pdf., p. 33-35. [Retrieved on 30 September, 2020]

Collins COBUILD Advanced English Dictionary, v. to feminize, HarperCollins Publishers, at https://www.collinsdictionary.com/it/dizionario/inglese/feminizes. [Retrieved on 27 September, 2020] 
Consortium on Gender, Security \&Human Rights, Feminist Critiques of the Sustainable Development Goals. Analysis and Bibliography, 2017, at https://genderandsecurity.org/sites/default/files/Feminist_Critiques_of_the_SDG S_-_Analysis_and_Bibliography_-_CGSHR.pdf, p. 5, [Retrieved on 30 September, 2020]

Convention on Biological Diversity, COP 5 Decision V/16, 15-26 May 2000, Nairobi Kenya, at <https://www.cbd.int/decision/cop/?id=7158>. [Retrieved on 30 September, 2020]

Christine Okali, Searching for New Pathways Towards Achieving Gender Equity. Beyond Boserup and 'Women's Role in Economic Development', in Esa Working Paper No. 11-09, March 2011, <http://www.fao.org/3/a-am314e.pdf. >. [Retrieved on 30 September, 2020]

Declaration of Santa Cruz de la Sierra and Plan of Action for the Sustainable Development of the Americas, Santa Cruz de la Sierra, Bolivia, 7 December 1996, at http://www.cumbre-americas.org/summit_sd/summit_sd_dec_en.pdf. [Retrieved on 29 September, 2020]

De Brauw Alan, Huang Jikun, Zhang Linxiu and Rozelle Scott, The Feminization of Agriculture with Chinese Characteristics, IFPRI Discussion Paper, 2012, at < http://ebrary.ifpri.org/utils/getfile/collection/p15738coll2/id/126960/filename/1271 71.pdf. $>$ [Retrieved on 27 September, 2020]

De Schutter, Olivier, Women's Rights and the Right to Food, A/ARC/22/50, 24 December 2012, p.14., at https://www.ohchr.org/Documents/HRBodies/HRCouncil/RegularSession/Sessi on22/AHRC2250_English.PDF. [Retrieved on 28 September, 2020]

Duckett Maryellen Kennedy, "Empowering Female Farmers to Feed the World", in National Geographic, at $<$ https://www.nationalgeographic.com/culture/article/partner-contentempowering-female-farmers $>$ [Retrieved on 12 September, 2020].

European Parliament, Directorate-General for Internal Policies, Women's Empowerment and Its Links to Sustainable Development, 2016, p.10, at < https://www.europarl.europa.eu/RegData/etudes/IDAN/2016/556927/IPOL_IDA( 2016)556927_EN.pdf>. [Retrieved on 27 September, 2020]

FAO, The Female Face of Farming, at $<$ http://www.fao.org/gender/resources/infographics/the-female-face-offarming/en/>. [Retrieved on 28 September, 2020]

FAO, The Role of Women in Agriculture, Esa Working Paper 11-02, March 2011, at <http://www.fao.org/3/am307e/am307e00.pdf.> [Retrieved on 28 September, 2020]

FAO, Gender-Disaggregated Data for Agriculture and Rual Development, Socio-Economic and Gender Analysis Programme, Rome, 2003, at < http://www.fao.org/3/al210e/al210e00.pdf.>. [Retrieved on 28 September, 2020]

FAO, Global Forum on Food Security and Nutrition, 17 July-6 August 2017, at < http://www.fao.org/3/a-i8222e.pdf>. [Retrieved on 28 September, 2020]

ILO, Implementing the ILO Indigenous and Tribal Peoples Convention No. 169.Towards an Inclusive, Sustainable and Just Future, 2019, at 
$<$ https://www.ilo.org/wcmsp5/groups/public/---dgreports/---dcomm/---

publ/documents/publication/wcms_735607.pdf,>. [Retrieved on 29 September, 2020]

Khachaturyan Marianna, Peterson Wesley F., "Does Gender Really Matter in Agriculture?", in Agricultural Economics, 2018,<https://agecon.unl.edu/cornhusker-economics/2018/does-gender-matteragriculture.pdf>. [Retrieved on 27 September, 2020]

Lambrecht Isabel, Schuster Monica, Asare Sarah and Pelleriaux Laura, "Changing Gender Roles in Agriculture?. Evidence from 20 Years of Dtat in Ghana", IFPRI Discussion Paper, march 2017, at < http://ebrary.ifpri.org/utils/getfile/collection/p15738coll2/id/131105/filename/1313 16.pdf>. [Retrieved on 27 September, 2020]

Lastarria-Cornhiel Susana, Feminization of Agriculture: Trends and Driving Forces, Background Paper for the World Development Report, 2008, p.1-21, at $<$ https://openknowledge.worldbank.org/handle/10986/9104>. [Retrieved on 28 September, 2020]

Maters Karen, The Nairobi World Conference, Women of Europe Supplement No. 24, Commission of the European Communities, Directorate-General Information, Communication, Culture Women's Information Service, 1986, p. 41, at < http://aei.pitt.edu/33993/1/A470.pdf>. [Retrieved on 28 September, 2020]

Mayer Elizabeth, The Power and the Premise of Ecofeminism, Reconsidered, in Honors Research Project, 1994, at $<$ https://digitalcommons.iwu.edu/cgi/viewcontent.cgi ?article=1007\&context=phil _honproj>. [Retrieved on 28 September, 2020]

Murali Vani Swarupa, In India and Africa, Women farmers lack land rights, in The Interpreter, 2012, at <https://www.lowyinstitute.org/the-interpreter/indiaand-africa-women-farmers-need-land-rights>. [Retrieved on 29 September, 2020]

Palumbo Letizia, Sciurba Alessandra, The Vulnerability to Exploitation of Women Migrant Workers in Agriculture in the EU: the Need for a Human Rights and Gender Based Approach, 2018, at <https://www.europarl.europa.eu/RegData/etudes/STUD/2018/604966/IPOL_S TU(2018)604966_EN.pdf>. [Retrieved on 28 September, 2020]

Pandit Ambika, Women from 'Farm Suicide Families' Demand Special Rehab Package, Uniform Compensation Policy, in The Times of India, January, 28, 2020, at <https://timesofindia.indiatimes.com/india/women-from-farm-suicidefamilies-demand-special-rehab-package-uniform-compensationpolicy/articleshow/73686539.cms.>. [Retrieved on 27 September, 2020]

Parpart Jane L. M., Connely Patricia and Barriteau V. Eudine (eds), Theoretical perspectives on Gender and Development, International Development Research Centre, Canada, 2000, at <https://prdidrc.azureedge.net/sites/default/files/openebooks/272-4/index.html\#page_161>. [Retrieved on 27 September, 2020]

Quesada-Aguillar Andre and Mata Gabriela, Gender And National Biodiversity Strategies And Action Plans (NBSAPs), Convention on Biological Diversity- 
IUCN fact sheet, https://www.cbd.int/gender/doc/fs_uicn-cbd_nbsaps.pdf. [Retrieved on 27 September, 2020]

Schuster Monica and Lambrecht Isabel, Gender Roles in Agriculture: Did Anything Change?, 2017, at <https://a4nh.cgiar.org/2017/10/25/gender-roles-inagriculture-did-anything-change/>. [Retrieved on 27 September, 2020]

Sen Gita, Alemany Cecilia, "SDG5 Advancing Women's Rights and Strengthening Global Governance: The Synergies", extract from the civil society report Stotlight on Sustainable Development 2019, at https://dawnnet.org/wpcontent/uploads/2019/07/Spotlight_Innenteil_2019_web_sdg5.pdf, [Retrieved on 30 September, 2020]

Smith Sarah, "Introducing Feminism in International Relations Theory", in Einternational Relations, 2018, at <https://www.e-ir.info/2018/01/04/feminism-ininternational-relations-theory/>. [Retrieved on 30 September, 2020]

Stephens Alexandra, Gender Issues in Agriculture and Rural Development Policy in Asia and the Pacific, FAO Regional Expert Consultation, 1995, at $<$ http://www.fao.org/3/x0177e00.htm>. [Retrieved on 28 September, 2020]

UNFPA, Guidelines on Women's Empowerment for the UN President Coordination System, United Nations Population Fund, UN Population Division, Department of Economic and Social Affairs, 1995, $<$ https://www.unfpa.org/sites/default/files/resource-

pdf/Guidelines_complete_text_without_figures_296K.pdf>. [Retrieved on 27 September, 2020]

Nan Zhu and Chang Lei, "Evolved but Not Fixed: A Life History Account of Gender Roles and Gender Inequality", in Frontiers in Psychology, available at < https://www.ncbi.nlm.nih.gov/pmc/articles/PMC6664064/pdf/fpsyg-10-

01709.pdf >. [Retrieved on 27 September, 2020]

UNHR and UNWomen, Realizing Women's Rights to Land and Other Productive Resources, HR/PUB/13/04, United Nations, New York/Geneva, 2013

https://www.ohchr.org/Documents/Publications/RealizingWomensRightstoLand. pdf $>$ [Retrieved on 30 September, 2020]

UN Office of the Special Adviser on Gender Issues and Advancement and the Secretariat of the United Nations Permanent Forum on Indigenous Issues, "Gender and Indigenous People's Human Rights, Briefing Note no. 6, February 2010,

<https://www.un.org/esa/socdev/unpfii/documents/BriefingNote6_GREY.pdf> [Retrieved on 20 September 2020].

Yao Pauline, The Right to inherit in Customay Law: An Obstacle to Women's Emancipation in Ivory Coast, 2014, at <http://www.citego.org/bdf_fichedocument-1388_en.html>. [Retrieved on 29 September, 2020] 